\title{
استخدام الخرائط الذهنية في تدريس الرياضيات لتنمية بعض مهارات التواصل الرياضي لدى تلاميذ المرحلة الإعدادية
}

\section{مخحم محمد معروف ع مان شاهين}

\section{ملخص :}

تمثل هدف البحث في التعرف على فعالية استخدام الخرائط الذهنية فى تدريس الرياضيات لتنمية

بعض مهار ات التواصل الرياضى لدى تلاميذ المرحلة الإعدادية وقد تكونت عينة البحث من مجدــوعتين

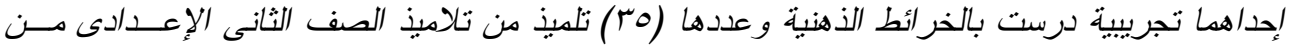

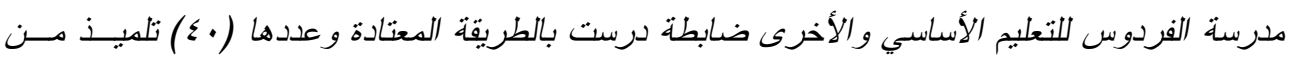

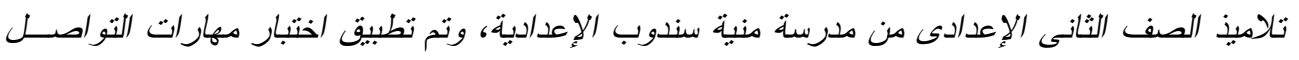

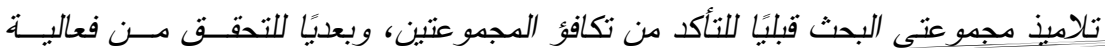

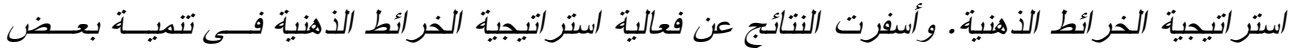

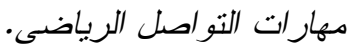

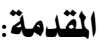

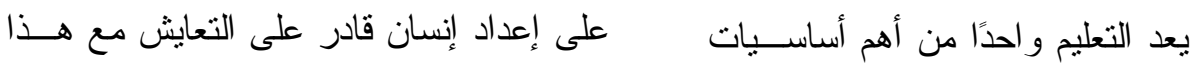

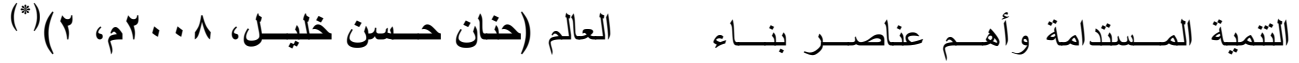

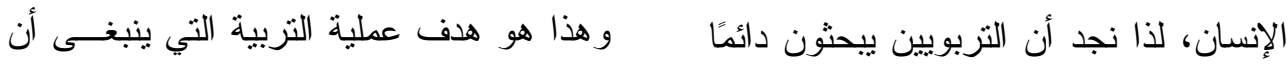

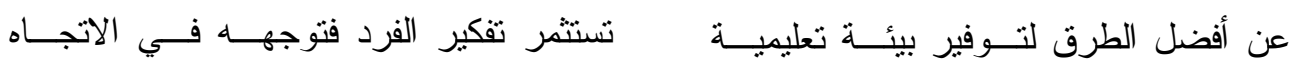

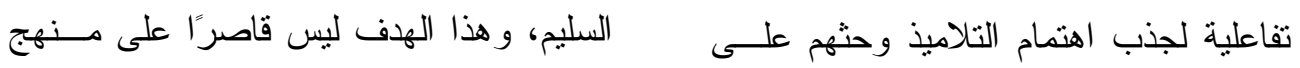

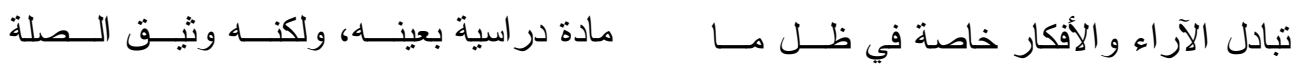

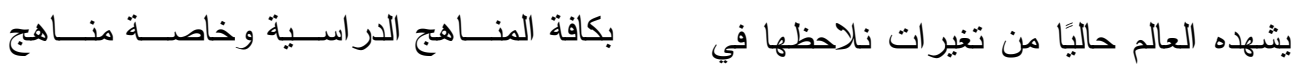

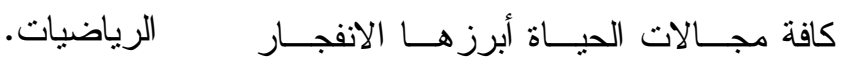

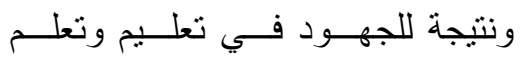
المعرفــي والتطــور الكبيــر فــي مجــال

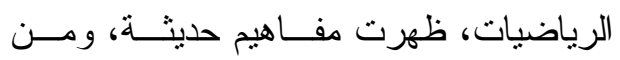
التكنولوجيا المعلومانية والإككترونية وتطور نظريات التعليم و التعلم لذا يجب على ولئ النظم

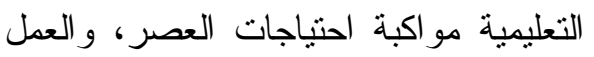




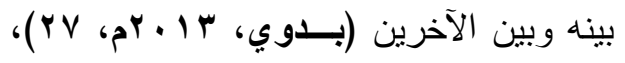

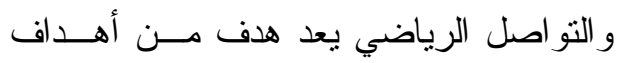

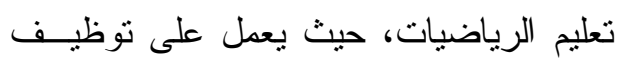

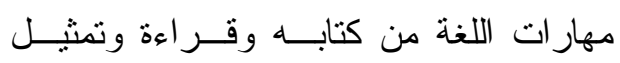

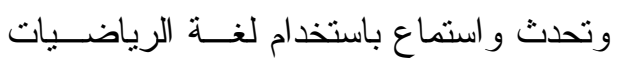
المكتوبة و المقرو عة، مما يجعل التلاميذ أكتــر

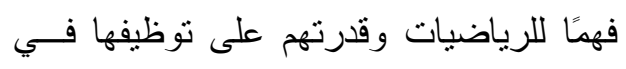

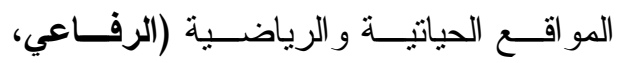

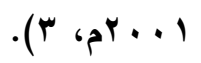

وللتو اصل الرياضي كما أثنار عفيفي

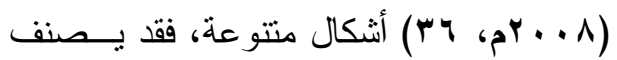

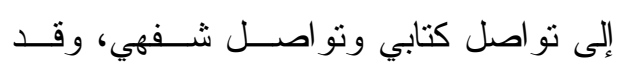

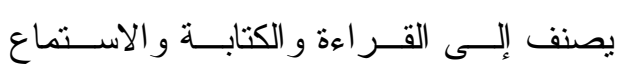
و التحدث و التمثيل.

ولقد تتاولت الكتثــر مــن الدر اســات طرق تتمية التو اصل الرياضي، ومنها دراسة جرينيس وآخرون ) Greenes \& others,

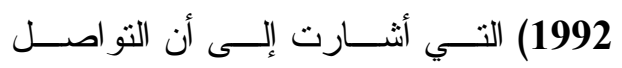

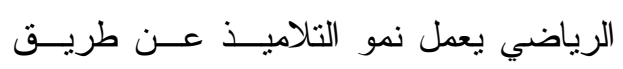

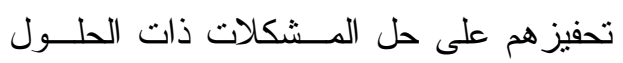
الكثيرة التي تحتاج إلى الابتكار و الاكتـشاف،

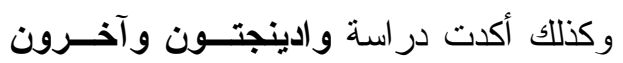
(Wadington \& others, 1992)

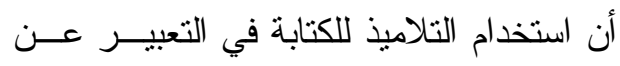
أفكار هم الرياضية عن طريق كتابــة المقـــال الرياضي يساعد في زيادة قدرة التلاميذ على لكئل

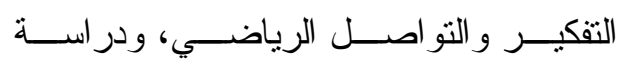

أهمها كفهوم القوة الرياضية، والتي تمثنـل هدفًا رئيسًا لتعليم الرياضيات. ويقصد بالقوة الرياضـية اكتـساب

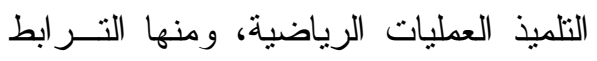

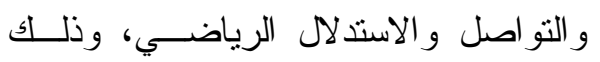

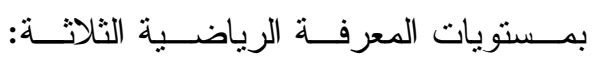

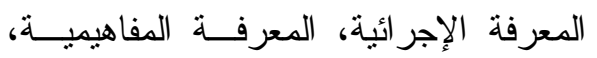
المعرفة المرتبطة بحل المشكلات، وذلك من الاجرته خلال محتوى رياضي معـين ) NCTM, (1989, 205

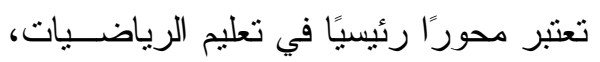

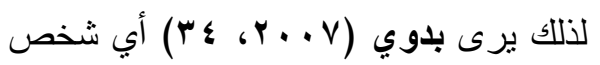

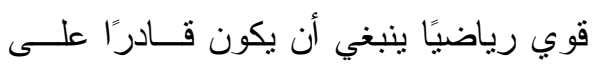

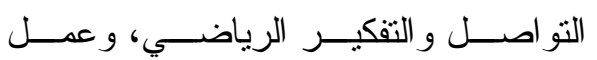

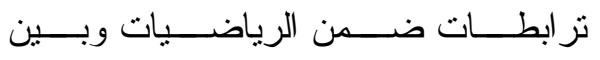
الرياضيات و المو اد الأخرى وحل المشكلات باستخدام الرياضيات.

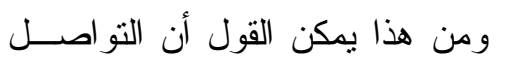

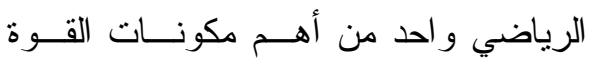

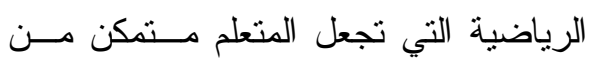

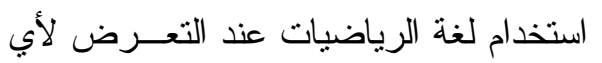

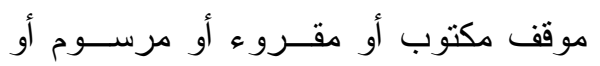

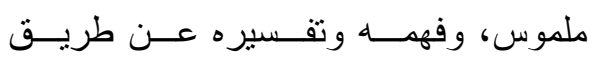

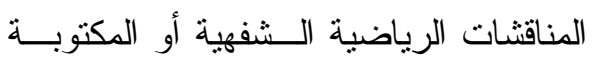

${ }^{(*}$ National Council of Teacher of Mathematics. 
أن يستخدمها، وذلك لما لها من فو ائد نربوية

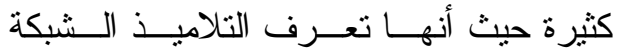
النز ابطية لعلاقات متداخلة من جو انب عديــدة بين عناصر الموضوع المراد عرضه،، وهذه التقينه تعمل على تحسـسين عمليتـي التعلــيم

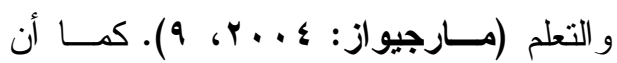

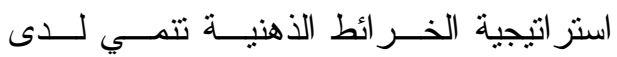

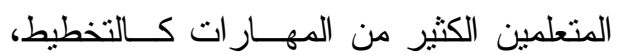

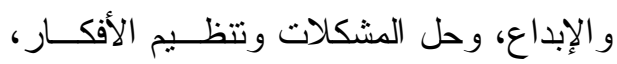

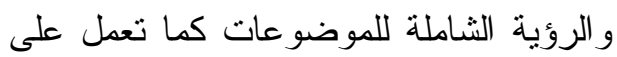
تتمية التفاعل الاجتماعي بين الطلاب (يوازن:

$$
.(9-\Lambda \text { ، } 4 . . .0
$$

و الخريطــــة الذهنيـــة عبــارة عــن

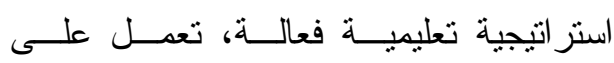

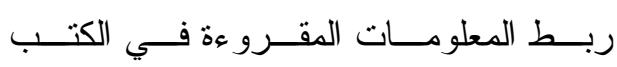
و المذكرات عن طريق رســومات وكلمــات

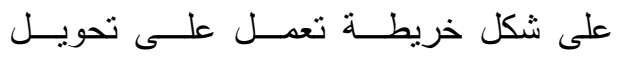

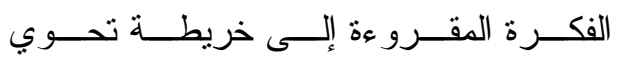
أثنكالاً مختصرة مزودة بــالألوان و الأثــكال في ورقة واحدة، حيث تعطي الطالب مساحة و اسعة من التفكير وتعطيه فرصـــة مر اجعــة

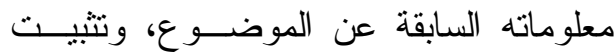
المعلومات و البيانات الجديــدة فــي منـــاطق المعرفة الذهنية (هديل أحمد وقــاء: 9 . . ب، $\cdot(r \cdot r$ مما سبق يمكن القــول أن الخريطــة

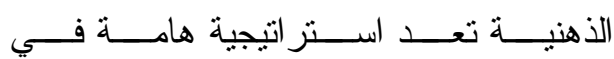

(راضي والحسيني، و99 ام) التي أكــدت على فاعلية المدخل اللغـــوي فــي تــدريس الرياضيات على النو اصل الرياضـــي فــي موضوع المساحات ودر اسة باركي ولـــين (Park \& lane, 1999) على تقويم أداء تلاميذ الصفوف المتوســـة

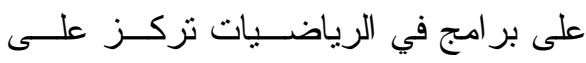
التو اصل الرياضي، و أظهرت نتائجها نمــوًا

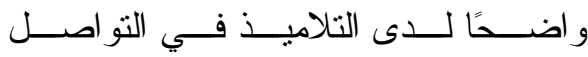
الرياضي. ويُيين ما سبق أن التو اصل الرياضي من الأهداف الرئيسية لتعليم الرياضيات في لئي

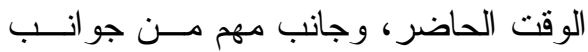

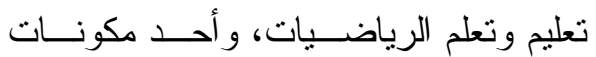
القوى الرياضية مما جعل تتميــة مهــار ات

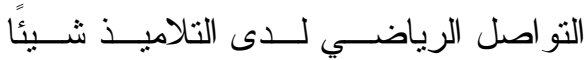

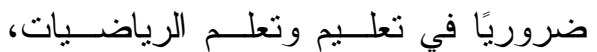

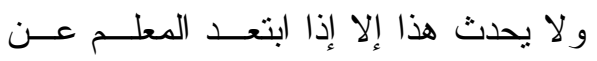

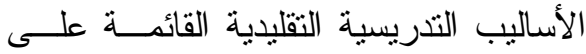

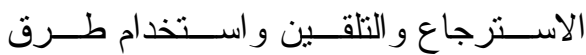
و واستر اتيجيات تشجع التلاميذ علـى إثـارة تفكير هم وتجعلهم محورًا للعملية التعليميــة

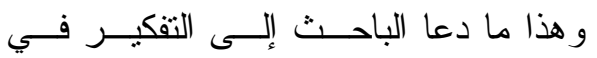
استز اتيجية تعليم حديثة تعمل علــى تتميــة مهار ات التو اصل الرياضي.

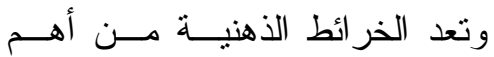
الاستر اتيجيات التي يمكن لمعلم الرياضيات 
تلامبذ المرحلة الإعدادية لا تتوفر لــديهم

مهار ات التو اصل الرياضـــي، ودر اســــة

إسكندر (1998م) التي وضّحت وجــود

ضعف لدى التلاميذ في المهار ات اللازمة

لقر اءة الرياضيات، ودر اســـة ســشوارز

(Schwarz, 1999) التي أثنارت إلـى (S)

ضعف مستوى تلاميذ المرحلة الإعدادية

في مهار ات التو اصل الرياضي، ودر اسة

هو جينزوميستا (

1999) التي أسفرت عن وجود قـصور

لدى تلاميذ المرحلة الابتدائية في مهار ات

$$
\text { الثفهي و الكتابي. }
$$

مشكلة البحث:

تتحدد مشكلة البحـــث فـي ضــــف

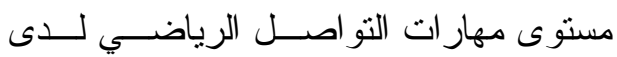

تلاميذ الصف الثاني الاعدادي ومدى الحاجـــة

إلى تتمية نلك المهار ات لديهح وقد سعت هذه

الدراسة إلى تحديد فاعلية استخدام الخــر ائط

الذهنية في تتمية بعض مهــار ات التو اصــلـ

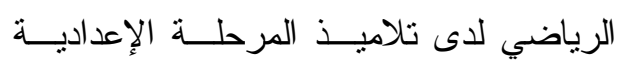

ويمكن تحديد مشكلة البحــث فــي التـساؤل

$$
\text { الرئيسي الآتي:- }
$$

ما فاعلية استخدام الخر ائط الذهنــة

في تدريس الرياضيات فـى تنميــة بعــ

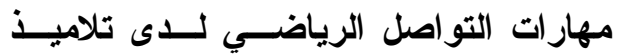

المرحلة الإعدادية".
تتميه مهار ات التو اصل الرياضي، إذ أنهــا تستخدم بفعالية لتتمية ودعم المستويات العليا لمهار ات التفكير، كما أنها تسـاعد التلاميــذ منخفضي التحصيل ليصلو ا إلى المـستوى

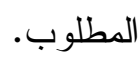

الشعوربالشكلة:

استثعر الباحث بمشكلة البحث الحالي من خلال عدد من الثو اهد الآتية:

- من خلال عمل الباحث كمعلم رياضيات بالمرحلة الإعدادية لاحظ الباحث وجود

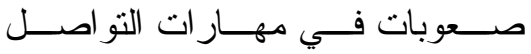
الرياضي لاى تلاميذ المرحلة الإعدادية عمومًا وتلاميذ الصف الثاني الاعدادي بصفة خاصة، وتم التأكد من ذلك أيضًا بسؤال عدد كبير من الزملاء المعلمين في مادة الرياضيات العاملين بـــوزارة

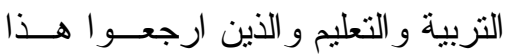

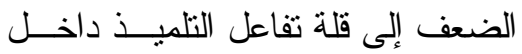
الصف الدر اسي، وضعف دوره داخـلـ عملية الــتعلم، و اعتمــاد كثيــر مـــن المعلمين على الطـــرق العاديـــة فــي تدريس الرياضيات و التي لا تعمل على إثارة تفكير التناميذ هو محور العمليــة

$$
\text { التعليمية. }
$$
- ما أكدته كثير من الدر اسات الــسابقة، مiedesel, ) مثـل در اســـة ريدســل 1995) الني أكدت على أن 58\% من 


$$
\begin{aligned}
& \text { تتمية مهارة القـــر اعة الرياضـــي لــدى } \\
& \text { تلاميذ المرحلة الإعدادية. } \\
& \text { r- التعرف على فاعلية استخدام الخــرائط } \\
& \text { الذهنية فى تدريس الرياضيات في نتمية }
\end{aligned}
$$

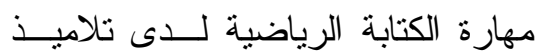

$$
\begin{aligned}
& \text { المرحلة الإعدادية. } \\
& \text { ع - التعرف على فاعلية استخدام الخــــائط } \\
& \text { الذهنية فى تدريس الرياضيات في تتمية }
\end{aligned}
$$

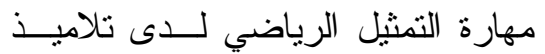

$$
\begin{aligned}
& \text { المرحلة الإعدادية. }
\end{aligned}
$$

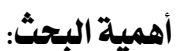

يقدم هذا البحث اســتر اتيجية تـسـاعد

الطالب على توليد كم هائل من الأفكار عـن لئن

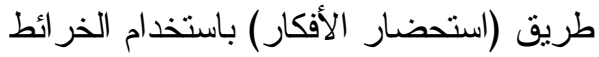

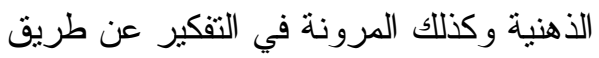
استخدام أكثر من خريطة حسب الموقف فهي

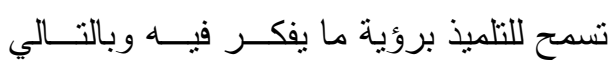
تعكس ما تم تعلمه في عقو لهم. 1-مساعدة معلمي الرياضيات فى التعرف

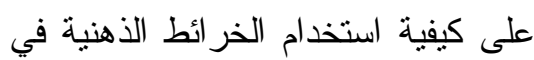
تدريس مادة الرياضيات.

r-تـــــاعد معلمـــى الرياضـــيات علــى

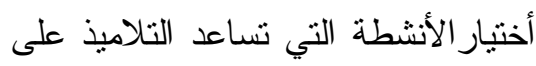
تتمية مهار ات التو اصل الرياضي لديهم. ب- التجديد في طــرق التــدريس الــسائدة ومساعدة المعلم على تقديم موضوعات

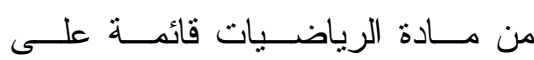

ويتفرع من هذا التساؤل الرئيسي التساؤلات الفرعية الآتية:-

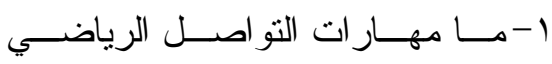

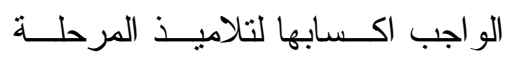

$$
\text { الإعدادية. }
$$

ץ-ما فاعلية استخدام الخر ائط الذهنية فى

تدريس الرياضيات في تتمية مهـارة

القراءة الرياضية لاى تلاميذ المرحلة

$$
\text { الإعدادية }
$$

ب-ما فاعلية استخدام الخر ائط الذهنية فى تئ

تدريس الرياضيات في تتمية مهــارة

الكتابة الرياضدىة لدى تلاميذ المرحلة

$$
\text { الإعدادية. }
$$

ع-ما فاعلية استخدام الخر ائط الذهنية فى

تدريس الرياضيات في تتمية مهـارة التمثيل الرياضى لدى تلاميذ المرحلة

$$
\text { الإعدادية. }
$$

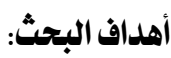

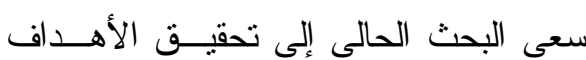

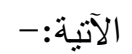

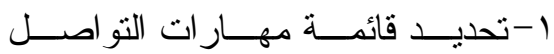

الرياضي الو اجب تو افرها لدى تلاميذ

$$
\text { المرحلة الإعدادية. }
$$

r- التعرف على فاعلية استخدام الخرائط

الذهنية فى تدريس الرياضــيات فـي 
1 - الحدود الزمانية: طبق البحث الحــالى

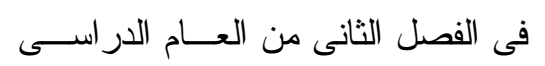

$$
. r \cdot 19-r \cdot 11
$$

r- الحـــدود المكاتيــة : أجــرى البحــــث

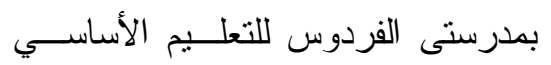

(إدارة غرب المنــصورة التعليميــة)؛

مدرسة منية سندوب الإعداديــة (إدارة

$$
\text { غرب المنصورة التعليمية). }
$$

r- الحدود الموضوعية: مهارات التو اصل

$$
\text { الرياضي (القر اءة - الكتابة - التمثيل) }
$$

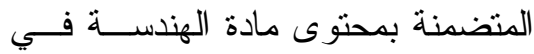

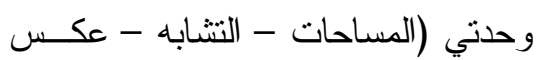

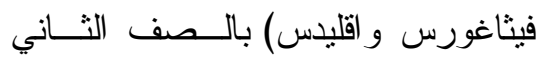

الاعدادي للفصل الدر اسي الثاني.

ع - الحدود البشرية: اختبار عينة من تلاميذ

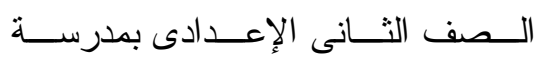

الفردوس للتعليم الأساسي (إدارة غرب الإب لمن

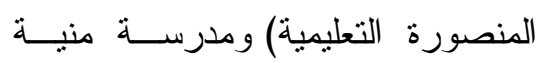

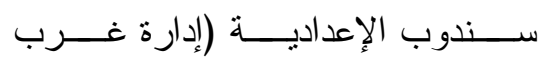

المنصورة التعليمية) ونم نوزيعهم على الاعدان

$$
\text { مجموعتين على النحو التالى: }
$$

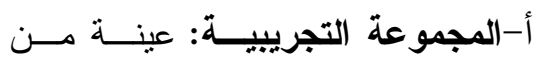

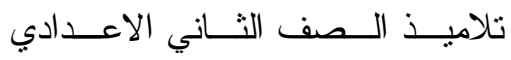

بمدرسة الفردوس للتعلــيم الأساسـي لاعي

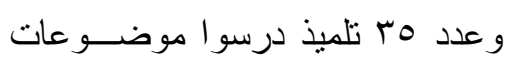

مقرر الهندسة باستخدام اســنز اتيجية

الخر ائط الذهنية.
استر اتيجية الخـــر ائط الذهنيــة، إلــى

جانب تقديم مجموعة مسـن الأنـشطة

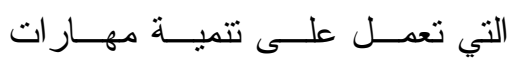

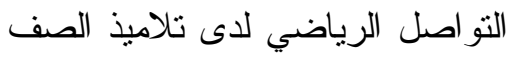

$$
\text { الثاني الاعدادي. }
$$

ع-تساعد المهتمين بتتمية وتطوير مناهج

الرياضيات إلى أهميــة اســتر اتيجية

الخر ائط الذهنية فــي تــدريس مــادة الفيا

الرياضيات.

0-توجيه أنظار موجهي مادة الرياضيات

إلى التحول من شكل التدريس التقليدي

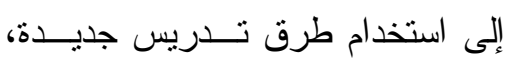

وتوجيه المعلمين لاستخدام هذه الطرق

الجديدة في التذريس.

7-تعمل هذه الاستر اتيجية على الارتقاء

بمستوى التعليم و اتباع الطرق الحديثة

$$
\text { في التدريس. }
$$

V- انتقال أثز استخدام الاسنر اتيجية فــي

التعبير عن المشكلات الحياتية وكيفية

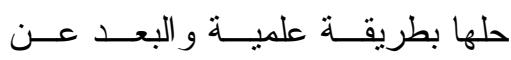

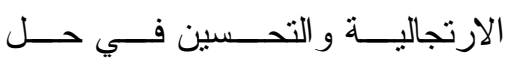

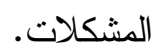

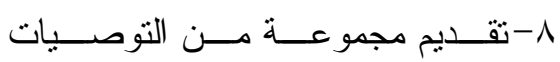

و المقترحات التي تساعد الباحثين فـي مي لئي

إجراء العديد من الدراسات و البحوث

ذات الصلة بمجال البحث.

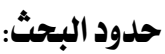

تمثل حدود البحث الحالى على:- 
- كر اسة النشاط معدة وفقًّـا لإســتر اتيجية

الخر ائط الذهنية في تدريس الموضوعات

$$
\text { منهج البحث: المختارة (إعداد الباحث). }
$$

اتبع البحــث الحــالى المــنهج شـــبه

التجريبى حيث تضمن البحــث مجمــوعتين

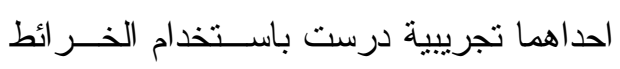

الذهنية و الأخرى ضابطة درســت باســـتخدام

الطريقة المعتادة. وقد تــم تطبيــق اختبــار

التواصل الرياضي على المجمــوعتين قبليــاً

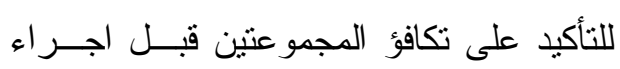

المعالجة التجريبية وأيضاً تطبيــق الاختبـــار

بعدياً لمعرفة مدى دلالة المعالجة التجريبيـة لفيـة

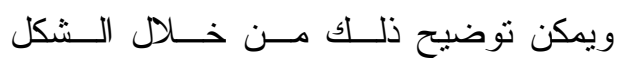

$$
\text { التخطيطي التالي: }
$$

ب- المجموعة الضابطة: عينــة مــن

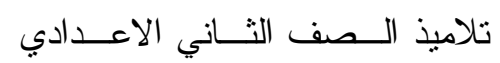

لمدرسة منية ســندوب الإعداديــة

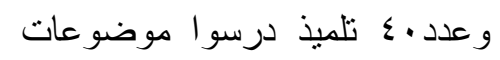

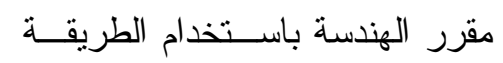

$$
\text { المعتادة في التنريس. }
$$

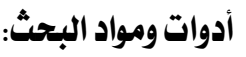

أولاً: أدوات البحث وتمثلث في:

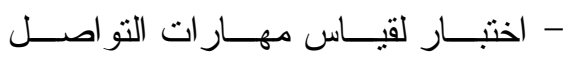

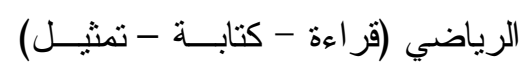

لتلاميذ المرحلة الإعدادية.

ثناتيًا: مواد البحث وتمثلث في:

- دليل للمعلم يوضـــح كيفيــة اســتخدام

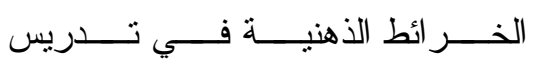

الموضو عات المختارة (إعداد الباحث).

ويوضح الثكل التالى التصميم التجريبى (التصميم القبلى | البعدى) لمجموعتين متكافئتين:

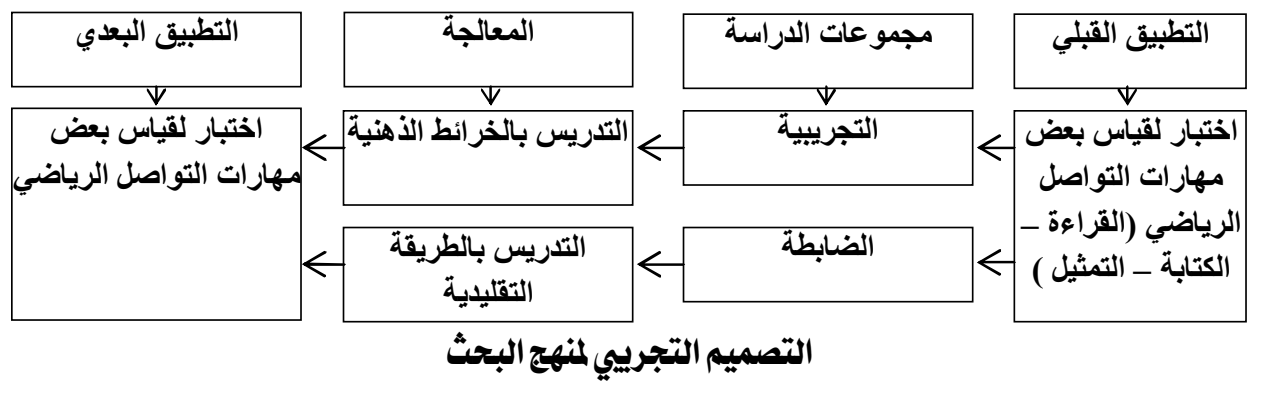

لزيادة دافعية المتعلم ونتجعه على الاستمرار

مصطلحات البحث:

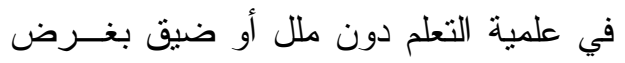

تحقيق الأهداف التعليمية المرجوة.

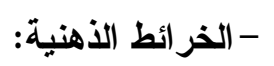

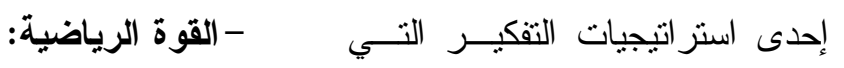

ويعرفها الباحث إجرائيًا بأنها:

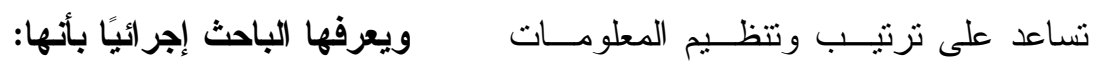

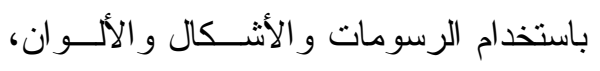


درجات تلاميذ المجمو عتين (الــضابطة و التجريبية) فى التطبيق البعدى لمهــارة الكتابة لصالح المجموعة التجريبية. ع-يوجد فرق ذو دلالـــة إحـصائية بـين متوسطى درجات تلاميــــ المجموعـــة التجريبية فى التطبيقين (القبلى و البعدى) لمهارة الكتابة لصالح التطبيق البعدى.

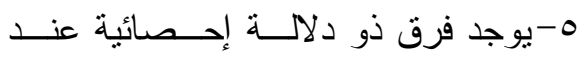

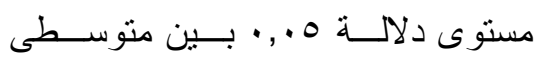
درجات تلاميذ المجموعتين (الــضابطة و التجريبية) فى التطبيق البعدى لمهـارة

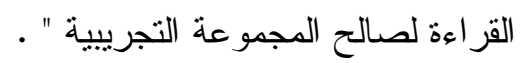
7-يوجد فرق ذو دلالــة إحـصائية بــين

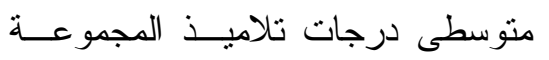
التجريبية فى التطبيقين (القبلى و البعدى) لههارة القر اءة لصالح النطبيق البعدى.

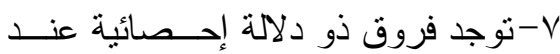

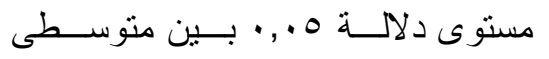

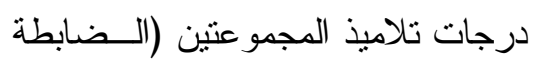

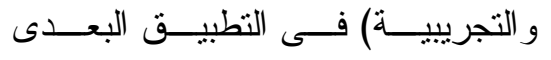
لاختبار التو اصل الرياضى ككل لــــالح المجمو عة التجريبية ". 1-توجد فروق ذو دلالة إحـصائية بـين

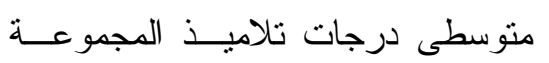
التجريبية فى التطبيقين (القبلى و البعدى) لاختبار التواصل الرياضى ككل لصالح

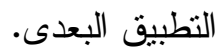

عملية ترتبط بالمعرفــة الإجرائيــة و المشكلاتية، وتبدأ من الإستماع و الحـــوار

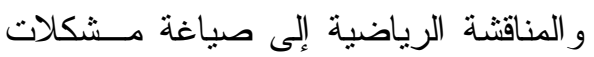

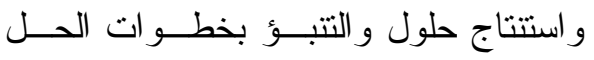
وتوقع مشكلات و استتناج معارف جديدة. - التو اصل الرياضي: ويعرفه الباحث إجر ائيًا بأنه:القــدرة علــى اســتخدام مفــردات التهات

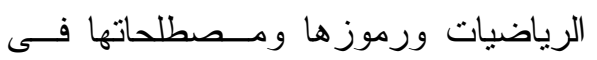

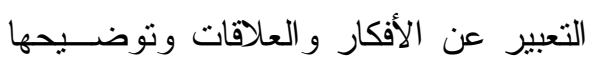

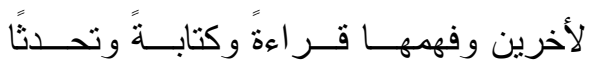
و استماعًا وتمثيلاً.

\section{فروض البحث:}

في ضوء أدبيات البحث و الدر اسات السابقة صيغت فروض البحث على النحو التالي:-

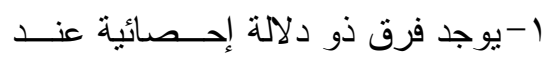

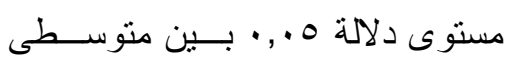
درجات تلاميذ المجمو عنين (الضابطة

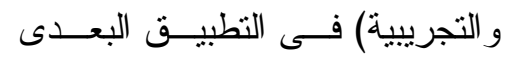

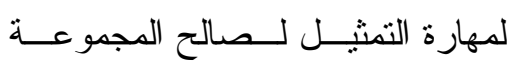
التجريبية . r-يوجد فرق ذو دلالة إحــصائية بــين متوسطى درجات تلاميذ المجموعـــة

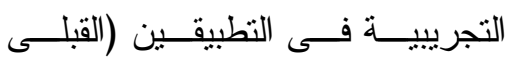

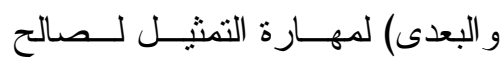
التطبيق البعدى.

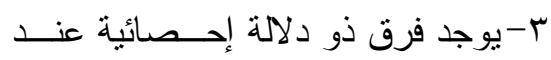

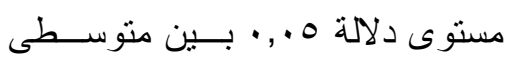


الصف الثاني الاعدادي ومؤشـــرات تحققهــا

إجرايات البحث

أولاً: اعداد قائمة بمهار ات التو اصل وذللك من خلال الجدول التالي:

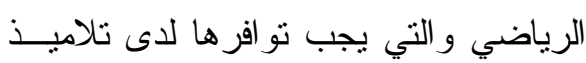

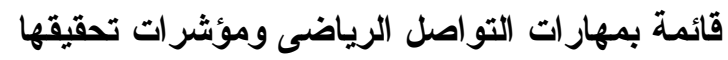

\begin{tabular}{|c|c|}
\hline مؤشر تحقيق المهارة & المهارة الرئيسية \\
\hline 1- يترجم النص الرياضي لصياغات منكافئة. & \multirow{4}{*}{ (1) مهارة التمثيل الرياضي: أبي } \\
\hline r- يعبر عن الأفكار الهندسية بصورة كتابية. & \\
\hline r- يترجم الأشكال الهندسية إلى نص رياضي. & \\
\hline ع - يترجم النصوص الرياضية إلى أنثكال هندسية. & \\
\hline 1 - يوضح التعميمات الرياضية المستخدمة للآخرين. & \multirow{4}{*}{ 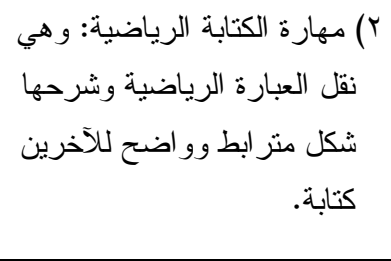 } \\
\hline r - بسمى المفاهيم الرياضية المستخدمة. & \\
\hline r- شرح العلاقات الرياضية التي يتضمنها النص الرياضي للآخرين. & \\
\hline ع - يلخص ما فهمه من أفكار و إجر اءات وحلول للآخرين. & \\
\hline 1- يستخدم لغته الخاصة لنقريب المفاهيم و الأفكار الهندية & \multirow{4}{*}{ ب) مهارة القر اعة الرياضية: هي } \\
\hline 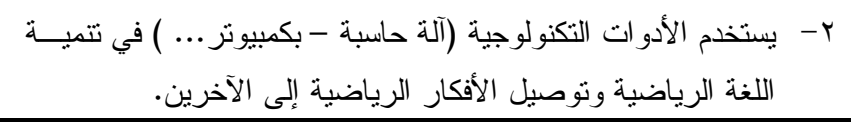 & \\
\hline r- يتخدم لغته الخاصة لتفسير النصوص الرياضية المكتوبة بوضوح. & \\
\hline ع - يصف العلاقات الرياضية المتضمنة في شكل هندسـي أو مــشكلات & \\
\hline
\end{tabular}

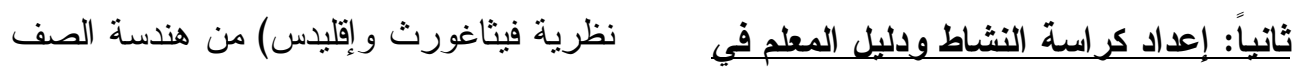
الثاني الإعدادي الفصل الدر اسي الثاني للعسام ضوع استر اتيحية الخر ائط الذهنية:

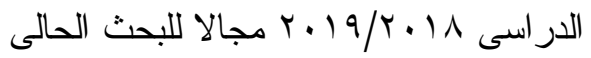
تم إعداد كر اسة النشاط ودليل المعلم ومن ثم عمل تحليل محتــوى لمقــرر وفقاً للخطو ات التالية: هندسة الــصف الثـانى الإعـــادى الفــصل

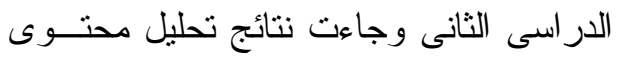

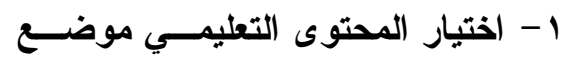
التطبيق ومبررات اختياره:

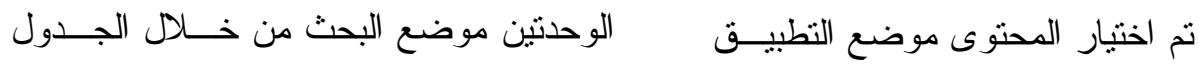

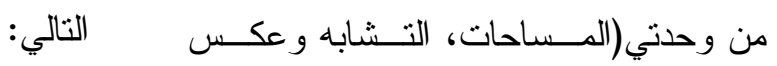


نتائج تحليل محتوى مقرر الهندسة للصف الثانى الإعدادى

\begin{tabular}{|c|c|c|c|c|}
\hline النسبة المئوية & المجموع & الثانية & الأولى & الوحدة \\
\hline$\% q, 1$ & 0 & $r$ & r & المفاهيم \\
\hline$\% \leqslant r, \tau$ & $r \varepsilon$ & 1. & $1 \varepsilon$ & التعميمات \\
\hline$\% \leqslant \gamma, r$ & ז & r & r & المهار ات \\
\hline$\% 1 \ldots$ & 00 & & & \\
\hline
\end{tabular}

ثانيًا: إعداد أدوات البحث:

1- إعداد كراسة النشاط:

حيث أن البحث الحالي يهـدف إلـى

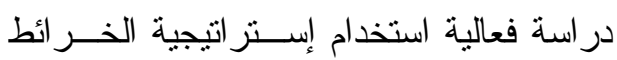

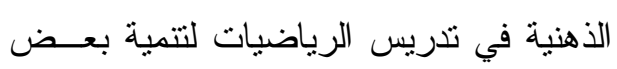
مهار ات التو اصل الرياضي، نم إعداد اختبــار

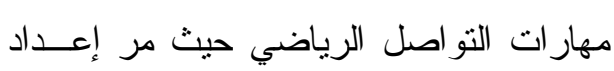
الاختبار بالخطو ات التالية:

( ) تحديد الاخهف من الاختبار: r ) صباغة مفردات الاختبار:

ولصياغة مفردات هذا الأختبــار تـم

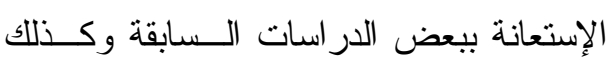

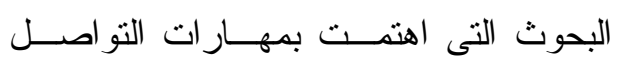
الرياضى وذلك لإستفادة منها فى هذه الجزئية

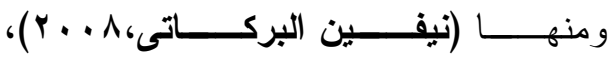

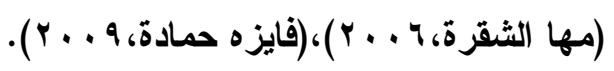
كما تم الإســتعانة بمحتــوى كتــاب

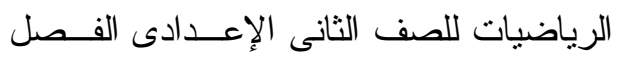

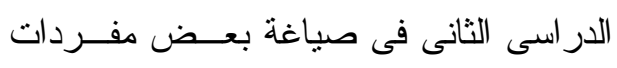
الإختبار، وتكون الإختبار من (؟ب) مفــردة

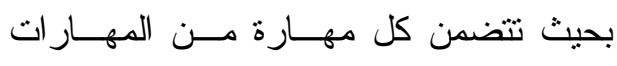

تم إعداد موضوعات مقرر الهندســـة

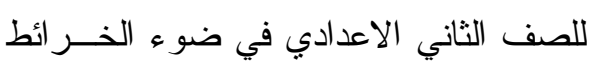

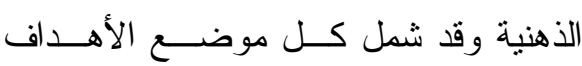

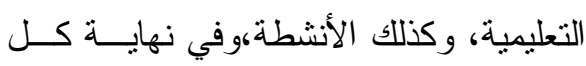
درس تضمن مجموعــة مــن التـدريبات ووفرت الأنشطة التعليميــة فــرص أمــام التلاميذ للتفاعل و إبداء الر أي وتدوينها فــي لإنيطي الأماكن المخصصة لها.

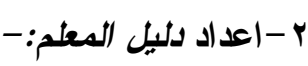
تم إعداد دليل المعلــم فـــي مقـرر الهندسة للصف الثاني الاعدادي بما يتضمنه من موضو عات فــي ضـــوء إســتر اتيجية

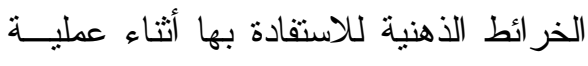

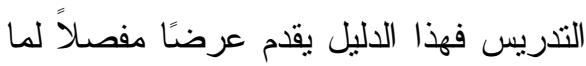
جاء في جميع دروس الوحدتين، والتي تـــ القيام بها أثناء النطبيق المبداني للبحث درون لونين 
التو اصل الرياضــى مــن حيــث مهـــار ات

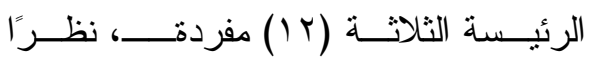

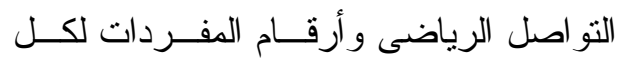

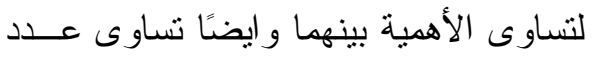
مهارة و الوزن النسبى لكل مهارة.

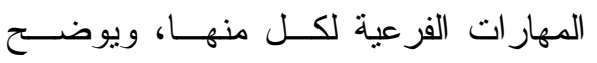

الجدول التالي مو اصفات اختبــــار مهــار ات وئه

\begin{tabular}{|c|c|c|c|}
\hline الكل مستوى النسبي & عدد الأسئلة لكل مستوى & كل الأسئلة التي يتضمنها & ستوى الاختبار \\
\hline \%rr,rr & ir & $r r-1$ & التشثيل \\
\hline \%rr, & ir & $r \varepsilon-1 T$ & الكتابة \\
\hline \%rr,rr & ir & $r_{4}-r_{0}$ & القر اءة \\
\hline$\% 1 \ldots$ & צ & צץ & الاختبار ككل \\
\hline
\end{tabular}

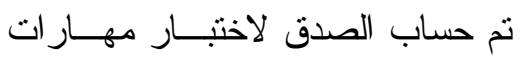

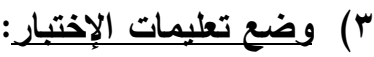

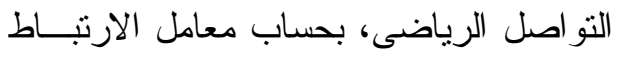

؛ ) إعداد مفتاح تصحيح الإختبار:

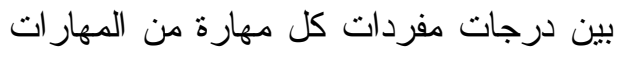

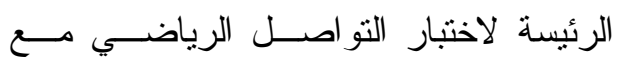

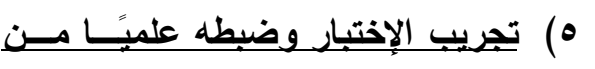

الدرجة الكلية لكل مهارة؛ وذلك كما يوضحه لألئ

خلا:

$$
\text { الجدول التالي: }
$$

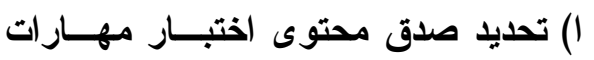

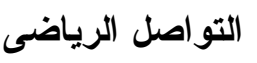

معاملات الارتباط بين كل مفردة من مفردات الاختبار مع الدرجة الكلية لكل مهارة

\begin{tabular}{|c|c|c|c|c|c|c|}
\hline 7 & 0 & $\varepsilon$ & $r$ & $r$ & 1 & \multirow{4}{*}{ التمثيل } \\
\hline$*, \varepsilon \ldots$ & $*, \varepsilon, \mu$ & $* *, 7 r q$ & $* *, 7 \wedge 9$ & $* *, \wedge 00$ & **,or & \\
\hline Ir & 11 & 1. & 9 & $\wedge$ & $\mathrm{V}$ & \\
\hline$* *, 771$ & $* *$, Nor & $* *, \wedge 00$ & ***, & $*, \leqslant \wedge 9$ & **, & \\
\hline 11 & IV & 17 & 10 & $1 \leq$ & r & \multirow{4}{*}{ الكتابة } \\
\hline ***, $\vee \vee V$ & ***,人 & **., qr. & **., OrV & $*, f \leq \leqslant \leq$ & $*$, \& O V & \\
\hline$r \varepsilon$ & rT & rY & $r$ & $r$. & 19 & \\
\hline$* *, 9 Y$. & $*, \leqslant \uparrow q$ & ***, $0 \vee 7$ & $* *, 9 Y$. & $*$, * \५q & $*, \varepsilon r V$ & \\
\hline$r$. & $r q$ & $r \wedge$ & $r V$ & $r_{T}$ & To & \multirow{4}{*}{ القر اءة } \\
\hline$* *, T Y 1$ & $* *, 07$. & $* *, V \backslash \leq$ & $* *, V \cdot \varepsilon$ & **, • T & $* *, V \cdot V$ & \\
\hline דץ & ro & $r \varepsilon$ & אי & rr & M & \\
\hline$* *, V \cdot \varepsilon$ & $*$, * I YO & $* *, \vee \vee 9 \wedge$ & $* *, T \leq \Gamma$ & $*, \leqslant \uparrow q$ & $* *, T \backslash \leq$ & \\
\hline
\end{tabular}

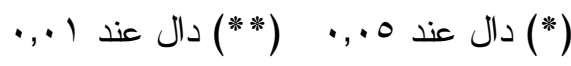


ولتحديد مدى اتساق درجات المهار ات

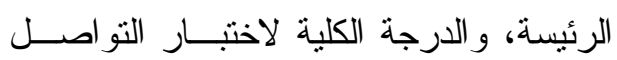

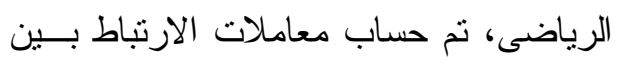

درجة كل مهارة رئيسـة، و الدرجـــة الكليــة

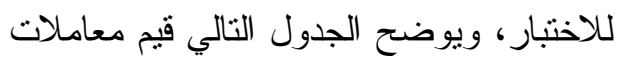

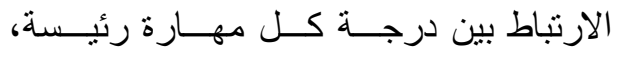

و الدرجة الكلية لاختبار التو اصل الرياضى دئي:
من خلال النتائج الني أسفرت عنها

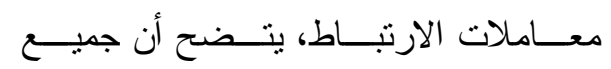

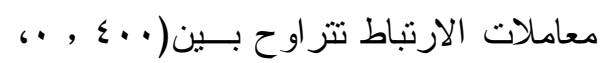

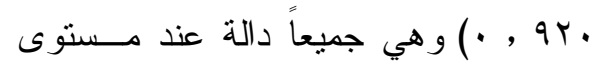

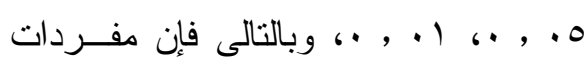

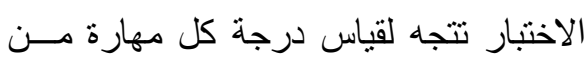

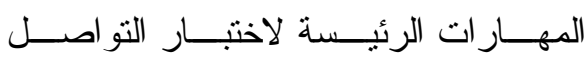

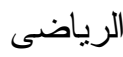

معاملات الارتباط بين الدرجة الكلية لكل مهارة والدرجة الكلية للاختبار

\begin{tabular}{|c|c|c|}
\hline 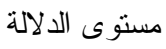 & معامل الارنباط بالنسبة للارجة الكلية & المهار ات المتضمنة باختبار مهار ات التو اصل الرياضى \\
\hline$\cdot, \cdot 1$ & $* *, \Lambda) r$ & 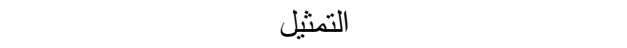 \\
\hline$\cdot, \cdot 1$ & $* *, \wedge \leq r$ & 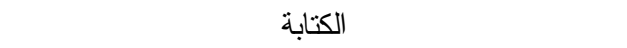 \\
\hline$\cdot, \cdot 1$ & 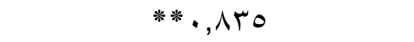 & القز اءة \\
\hline
\end{tabular}
(**) دال عند 1 (•,

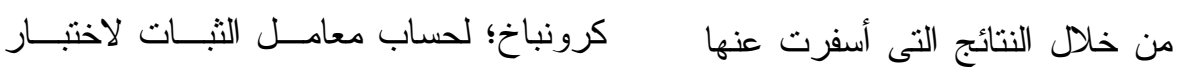

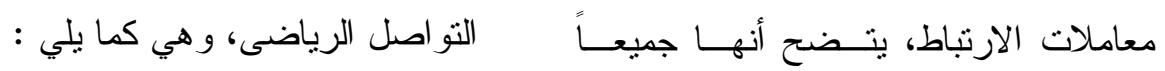

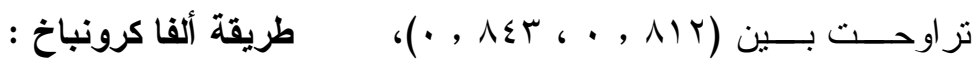

بعد تطبيق اختبار مهار ات التو اصـلـل

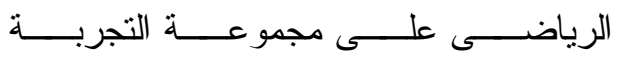

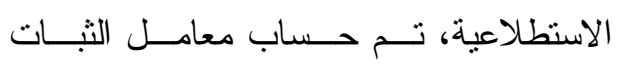

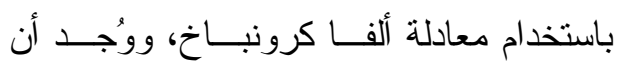

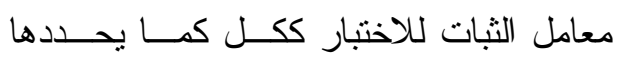

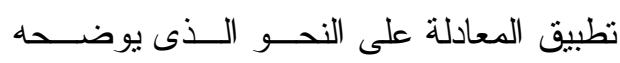
الجدول التالي :
وهى جميعها دالة عند مسستوى | +. . . وبذللك يكون الاختبار مُناسباً للتطبيق علـى دهى دهى مجمو عة البحث الأساسية. r) حســاب الثبــات لاختبــار التواصــل الرياضى

يُقصد بثبات الاختبـــار أن يُعطـى لئى

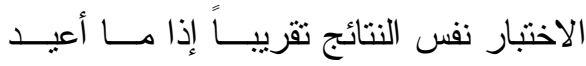
تطبيقه أكثر من مرة علي نفس الأفراد تحت نفس الظروف، وقد ثم استخدام طريقة ألفــا 
معامل ثبات ألفا كرونباخ لاختبار مهارات التواصل الرياضى

\begin{tabular}{|c|c|c|c|c|c|}
\hline معامل ثبات ألفا كرونباخ & التباين & $\varepsilon$ & م & ن ن & المهارات المتضمنة بالاختبار \\
\hline •, Аᄉ & $1 \%, 9 \leq$ & $r, \mathrm{~V} r$ & $\gamma, \varepsilon 0$ & ir & التثثيل \\
\hline$\cdot, \wedge \leqslant 9$ & $1 ., 0 \mathrm{~V}$ & r, ro & $\Lambda, \varepsilon$. & ir & الكتابة \\
\hline$\cdot, 101$ & IT,IY & $r, \sum \wedge$ & $\Lambda, r$. & ir & القز اوة \\
\hline - ,9ro & $v_{0, r q}$ & $\Lambda, \uparrow \wedge$ & $r \leqslant, 10$ & q & الاختبار ككل \\
\hline
\end{tabular}

ع) حساب معـاملات التمييـز لمفــردات

اختبار مهار ات التو اصل الرياضى .

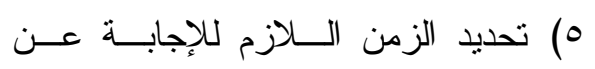

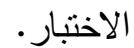

ثالثًا: اختبار عينة البحث:

\section{أ) مجتمع العينة:}

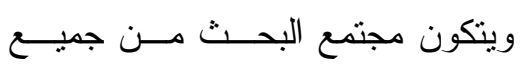

التناميذ بالصف الثانى الإعدادى فى المدارس لئرس

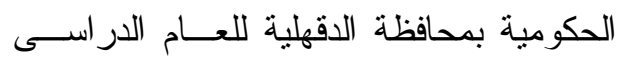

$$
\begin{aligned}
& \text {. }(r+19 / r \cdot 11) \\
& \text { ب) عينة البحث: }
\end{aligned}
$$

تم اختيار مدرستى الفردوس للتعلــيم

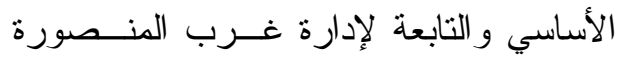

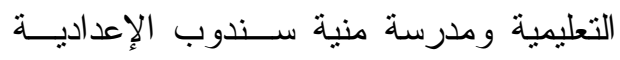

التابعة لإدارة غرب المنصورة التعليمية وبلغ

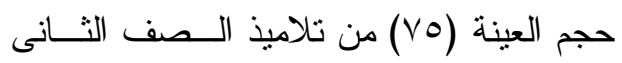

الإعدادى، وقسمت العينة إلى مجمو عتين على نلى لئل

$$
\text { النحو الذى يوضحة الجدول النالى. }
$$

يتضح من الجدول السابق أن قـيم

معامل الثبات لمهار ات الاختبار نتر اوح من لن

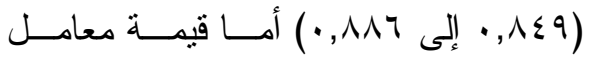
الثبات للاختبار ككل كما أسفر عنها تطبيق

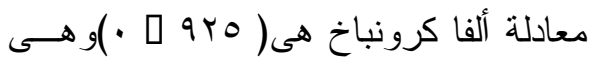

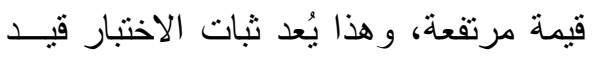

ب) التجربة الاستطلاعية لإختبار مهــار ات التو اصل الرياضى:

قام الباحث بتطبيق الاختبــار علــي

مجموعة استطلاعية (غير مجموعة البحث

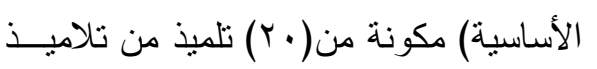

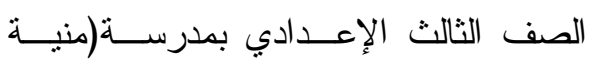
سندوب الاعدادية)؛ وذلك بهدف:

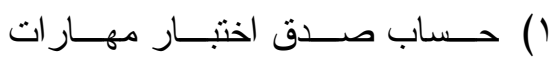

$$
\text { التو اصل الرياضى. }
$$

r) حساب ثبات اختبار مهار ات التو اصل لونل

$$
\text { الرياضى. }
$$

r) حساب معاملات السهولة و الصعوبة

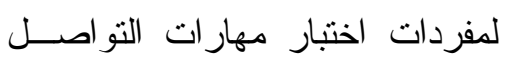

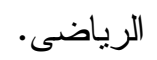




\section{مو اصفات عينة البحث}

\begin{tabular}{|c|c|c|c|c|}
\hline مجموع التلاميذ & الفصل & المعالجة التجريبية & اسم المدرسة & المجموعة \\
\hline ro & $r / r$ & الخر ائط الذهنية & الفردوس للتعليم الأساسي & التجريبية \\
\hline$\varepsilon$. & $r / r$ & الطريقة المعتادة & منية سندوب الإعدادية & الضابطة \\
\hline vo & & 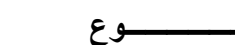 & 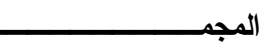 & \\
\hline
\end{tabular}

ومن الجدول السابق يتبين أن عينــة القائم على تصميم قبلى - بعدى لمجموعنين

تجريبية وضابطة، وفيه أخــنت المجموعــة

البحث اشتملت على(V0) تلميذ بو اقع (ب0) الأولى معالجة تجريبية تتمنل فــى اســتخدام وفيه

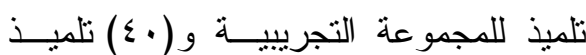

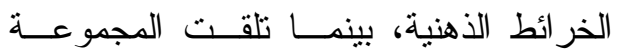
للمجمو عة الضابطة. الأخرى معالجة ضابطة تتمنل فــى الطريقـــة رابعًا: التصميم التجريبي للبحث: المعتادة فى التدريس.

استخدم الباحث المنهج شبه التجريبى ويوضح الثكل التالي التصميم التجريبي للبحث:

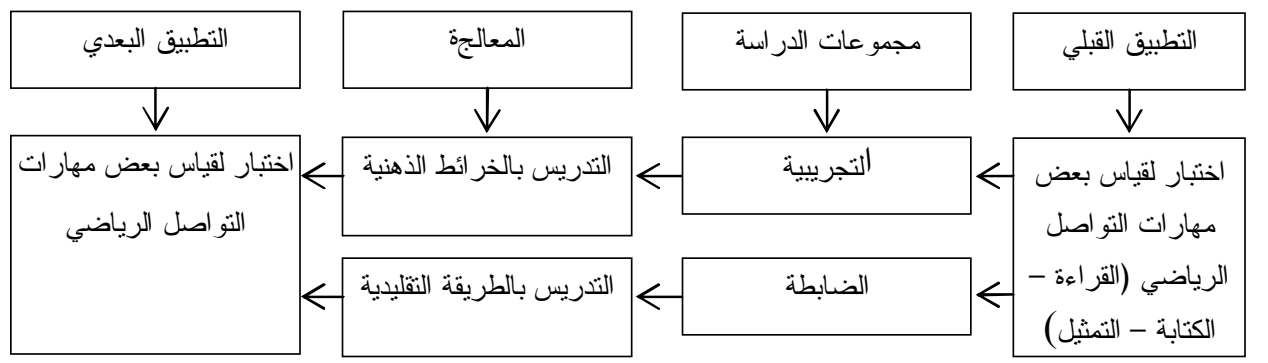

\section{التصميم التجريبى للبحث}

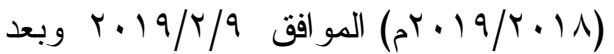
ذللك تم تصحيح الإختبار ورصد الــدرجات، للتأكد مــن تكــافؤ المجمــوعتين التجريبيـــة و الضابطة فى اختبار النواصل الرياضى. استخدم الباحث معادلة "ت" لمجموعنين غير مرتبطتين؛ لبحث دلالـــة الفـرق بــين متوسطي درجات كل من المجموعة التجرييية

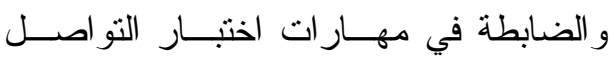

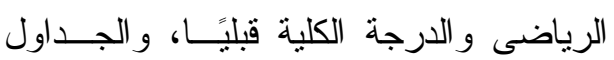

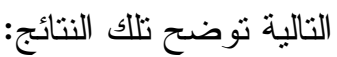

خامسًا: خطوات التطبيق المبدانحة: مر التطبيق الميدانى بثلاث مر احل و هى: المرحلة الأولـى : التطبيــق القبــــى لأداة البحث: - (البث: وتتمتــلـل فـى تطبيــق اختبـــار التواصــل الرياضى. تم تطبيق الاختبــار علــى تلاميــذ المجمو عتين (التجريبية-الضابطة) وذلك فى نى نلئي

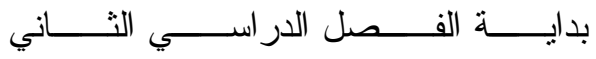


قيمة "ت" ودلالتها الإحصائية للفرق بين متوسطى درجات كل من المجموعة التجريبية والمجموعة الضابطة فى مهارة التمثيل قبلياً

\begin{tabular}{|c|c|c|c|c|c|c|c|c|}
\hline مستوى الدلالة & الدلالة & $ت$ & د. & $\varepsilon$ & P & ن & مجموعتا & مهارة التو اصل \\
\hline \multirow[t]{2}{*}{ غير دالة } & \multirow[t]{2}{*}{ זדוד, } & \multirow[t]{2}{*}{$\cdot$, • «^. } & \multirow[t]{2}{*}{$v r$} & $1, \leqslant r$ & $\{, Y \Psi$ & ro & ت & \multirow[t]{2}{*}{ التمثيل } \\
\hline & & & & $1, \varepsilon 1$ & $\varepsilon, 1$. & $\varepsilon$. & ض & \\
\hline
\end{tabular}

قيمة "ت" ودلالتها الإحصائية للفرق بين متوسطى درجات كل من المجموعة التجريبية والمجموعة الضابطة فى مهارة الكتابة قبلياً

\begin{tabular}{|c|c|c|c|c|c|c|c|c|}
\hline مستوى الدلالة & الدلالة & $ت$ & د.ح & $\varepsilon$ & p & ن ن & البحث & مهارة التو اصل \\
\hline \multirow[t]{2}{*}{ غير دالة } & \multirow[t]{2}{*}{$\cdot, \mathrm{YYA}$} & \multirow[t]{2}{*}{ • rरT } & \multirow[t]{2}{*}{ VT } & $r, q \mu$ & $r, r v$ & ro & ت & \multirow[t]{2}{*}{ الكتابة } \\
\hline & & & & r,Tr & . & $\varepsilon$. & ض & \\
\hline
\end{tabular}

قيمة "ت" ودلالتها الإحصائية للفرق بين متوسطى درجات كل من المجموعة التجريبية و المجموعة الضابطة فى مهارة القراعة والارجة الكلية قبلياً

\begin{tabular}{|c|c|c|c|c|c|c|c|c|}
\hline مستوى & الدلالة & $ت$ & ح. & $\varepsilon$ & p & ن ن & مجموعتا & مهار الترياضى التواصل \\
\hline \multirow[t]{2}{*}{ غير دالة } & \multirow[t]{2}{*}{$\cdot, 799$} & \multirow[t]{2}{*}{ 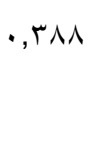 } & \multirow[t]{2}{*}{$v r$} & T, & $r, \varepsilon$. & ro & ت & \multirow[t]{2}{*}{ القر اءة } \\
\hline & & & & $r, v$. & $r, 1 \wedge$ & $\varepsilon$. & ض & \\
\hline
\end{tabular}

قيمة "ت" ودلالتها الإحصائية للفرق بين متوسطى درجات كل من المجموعة التجريبية و المجموعة الضابطة فى اختبار التواصل الرياضى قبلياً

\begin{tabular}{|c|c|c|c|c|c|c|c|c|}
\hline مستوى الدلالة & الدلالة & 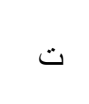 & ح.د & $\varepsilon$ & r & ن ن & مجمو البحثا & اختبار التو اصل \\
\hline \multirow[t]{2}{*}{ غير دالة } & \multirow[t]{2}{*}{$\cdot, T \cdot r$} & \multirow[t]{2}{*}{ •, Orr } & \multirow[t]{2}{*}{$v r$} & $\varepsilon, 9 \vee$ & $11, \varepsilon r$ & ro & 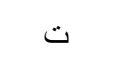 & \multirow[t]{2}{*}{ الاختبار ككل } \\
\hline & & & & $\varepsilon, r_{1}$ & $1 \cdot, \wedge \wedge$ & $\varepsilon$. & ض & \\
\hline
\end{tabular}


2019/4/1م، وقد استغرق التـدريس

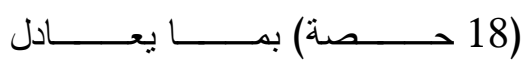

$$
\text { (8) (أسبابيع). }
$$

r. قام الباحث بتوفير الوسـائل و الأدوات

المستخدمة وفق الإستر اتيجية المتبعــة

$$
\text { فى التدريس و المتمنلة فى: }
$$

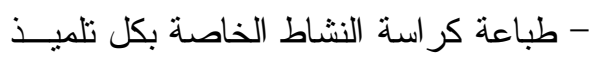

$$
\text { تلميذة داخل الفصل. }
$$

- تـــوفير أور اق عمـل للتنلاميــذ وكــــللك

$$
\text { تجهيز CD لعرضها على التلاميذ. }
$$

- نوفير الوسائل التعليمية المناسبة لتدريس

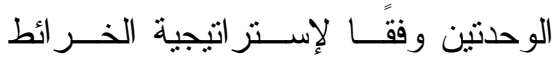

$$
\text { الذهنية. }
$$

- توفير أساليب التعزيز المناسبة لتـشيع

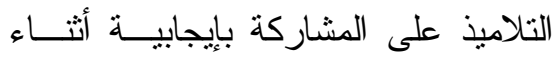

$$
\text { عملية التثريس. }
$$

المرحلة الثالثة: التطبيـق البعـدى لأدوات

$$
\text { البحث: - (لمرحله }
$$

بعد الإنتهاء من التدريس للمجموعــة

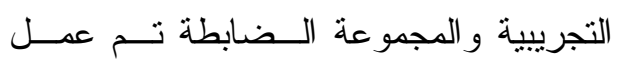

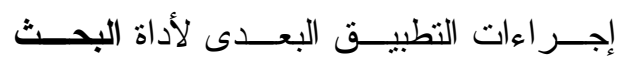

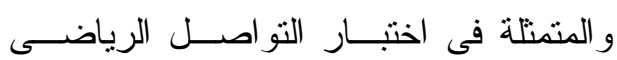

ورصد الدرجات تمهيدًا لمعالجتهـــا إحــصائيًا

ومن ثم التحقق من صحة فــروض البحـــث

$$
\text { و الحصول على نتائجه. }
$$

$$
\begin{aligned}
& \text { يتضح من الجــداول الــسابقة عــدم }
\end{aligned}
$$

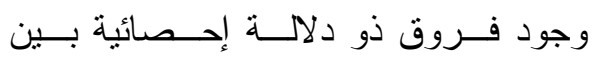

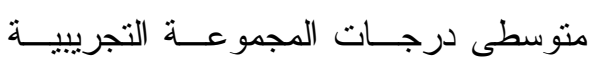

و المجموعة الضـابطة فى مهار ات الاختبـــار

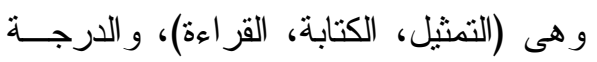
الكلية للاختبار ؛ حيث جاءت جميع قيم "ت أتئ

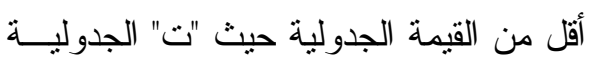

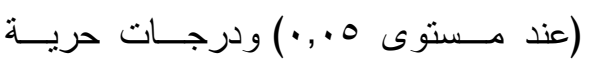

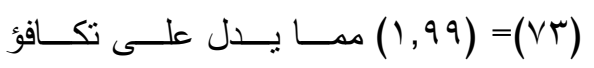

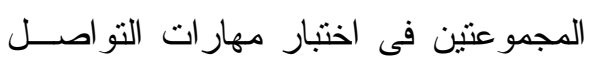

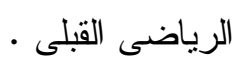
المرحلة الثانية: تنفيذ تجربة البحث: نم تتفيذ تجربة البحث الحالى فيما بلى:

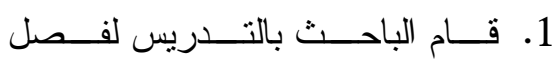

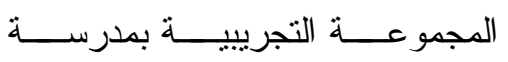
الفردوس للتعليم الأساســي التابعــة لإدارة غرب المنــصورة التعليميــة وذللك بإستخدام استر اتيجية الخــر ائط

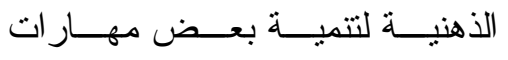
التو اصل الرياضى، وقامت معلمـــة من مدرسة منية سندوب الإعداديــة

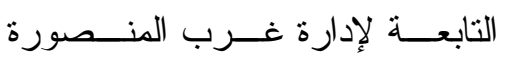
التعليمية بالتدريس لفصل المجموعـــة

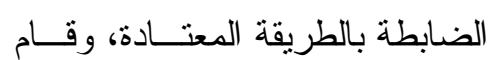

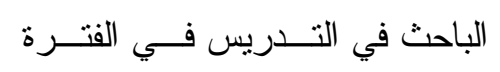

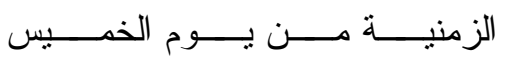

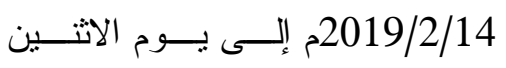


تلاميذ المجمو عتين (الضابطة و التجريبية) فى

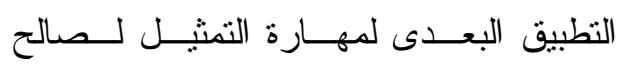

المجموعة التجريبية "استخدم الباحث معادلة "

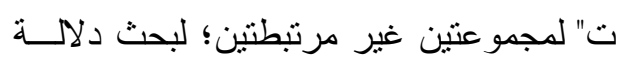

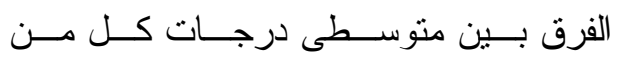
المجموعة التجريبية و المجموعة الضابطة فى دئ درني

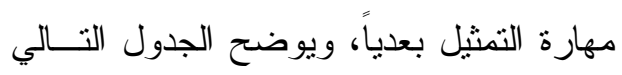
تلك النتائج :
فى ضو ء الإجر اءات التى اتبعها الباحــث، توصل البحث الحالى إلى النتائج التاليه: ثمأولاً : النتائج الخاصة بمهارة التمثيل : للتحقق من صحة الفرض الأول الذى ينص على : - 1 يوجد فرق ذو دلالة إحصائية عنـــد مستوى دلالة 0 ., • بين منوسطى درجــات دلات

قيمة "ت" ودلالتها الإحصائية للفرق بين متوسطى درجات كل من المجموعتين (التجريبية والضابطة) فى مهارة التمثيل بعدياً

\begin{tabular}{|c|c|c|c|c|c|c|c|}
\hline مستوى الدلالة & $ت$ & د.د & $\varepsilon$ & p & ن & مجموعتا البحث & مهار ات التواصل الرياضى \\
\hline \multirow[t]{2}{*}{ د لة } & 9 & $v r$ & $1, \wedge \wedge$ & $\Lambda, \varepsilon \Gamma$ & ro & ت & 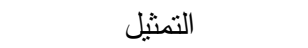 \\
\hline & & & $r, 19$ & $\varepsilon, 10$ & $\varepsilon$. & 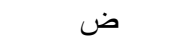 & \\
\hline
\end{tabular}

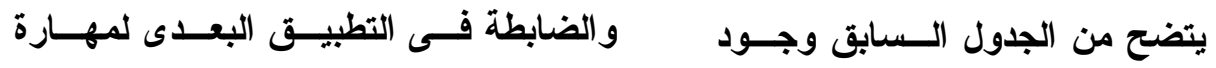

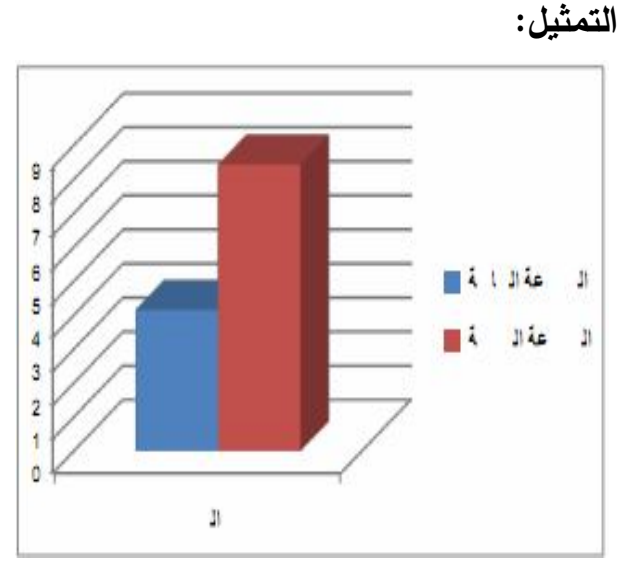

شكل (1): التمثيل البياني للفرق بين متوسطات

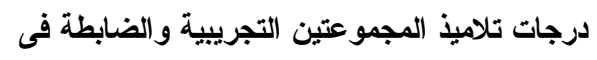
التطبيق البعدى لمهارة التمثيل
فروق ذو دلامة إحصائية بـين متوســطى

درجات المجموعة التجريبية والمجموعـة الضابطة فى مهارة التمثيل؛ حيث جــاعت قيمة " ت" أكبر من القيمة الجدولية حيث "

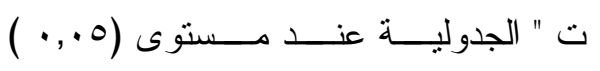

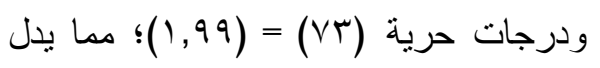
على تفــوق المجموعـــة التجريبيـــة علــى المجمو عة الضابطة فى مهارة التمثيل . ويوضتح الشكل التــالى (شــكل التمثيل البيانى للفـرق بــين متوســطات

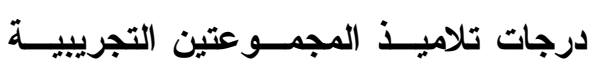


يوجد فرق ذو دلالة إحـصائية بـين

متوسطى درجات تلاميذ المجموعة التجريبية

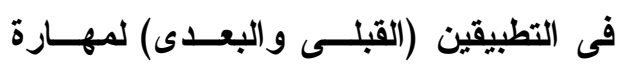
التمثيل لصالح التطبيق البعدى.

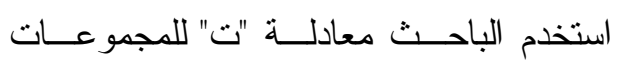

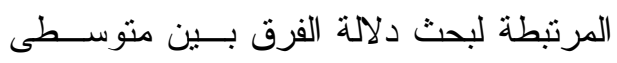

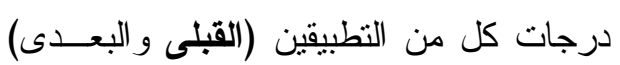

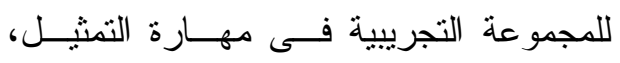

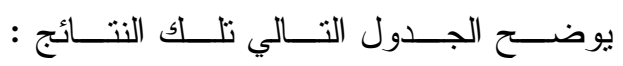

وفى ضوء تلك النتيجة، يمكن قبول الفرض الأول من فروض البحث وهو :

يوجد فرق ذو دلالة إحصائية عنــــ

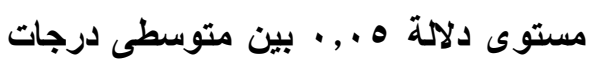
تلاميذ المجموعتين (الضابطة والتجريبية) فى التطبيق البعدى لمهارة التمثيل لصالح المجموعة التجريبية

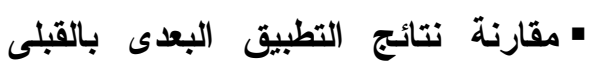
للمجموعة التجريبية فى مهارة التمثيل :

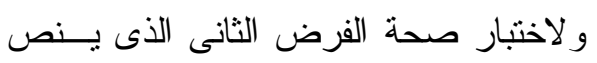
على : قيمة "ت" ودلالتها الإحصائية للفرق بين متوسطى درجات كل من التطبيقين (القبلى و البعدى) للمجموعة التجريبية فى مهارة التمثيل

\begin{tabular}{|c|c|c|c|c|c|c|c|}
\hline مستوى الدلالة & $ت$ & د.د & $\varepsilon$ & م & ن & 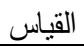 & مهار ات اختبار التو اصل الرياضى \\
\hline \multirow[t]{2}{*}{ دالة } & \multirow[t]{2}{*}{$1 r, r q$} & \multirow[t]{2}{*}{$r \varepsilon$} & $1, \wedge \wedge$ & $\Lambda, \varepsilon r$ & ro & 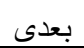 & \multirow[t]{2}{*}{ 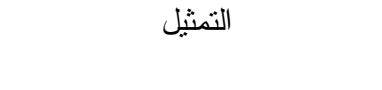 } \\
\hline & & & $1, \varepsilon r$ & $\varepsilon, Y_{\top}$ & ro & قبلى & \\
\hline
\end{tabular}

تلاميذ المجمو عة التجريبيــة فـــى التطبيقــين (القبلى و البعدى) لمهارة التمثيل : لمعبل

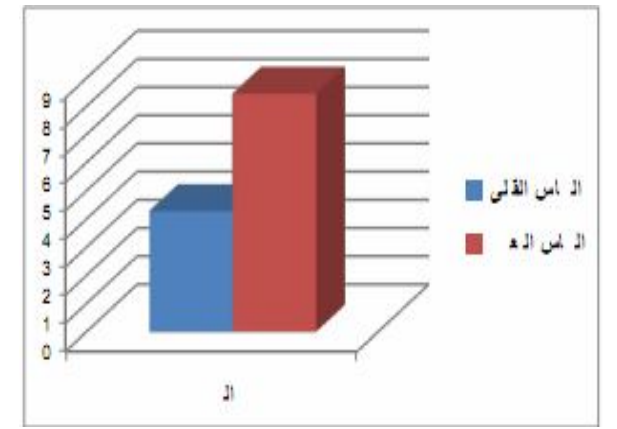

شكل (r):التمثيل البياني للفرق بين متوسطات درجات تلاميذ المجموعة التجريبية فى التطبيقين (القبلى والبعدى) لمهارة التمثيل
يتضتح من الجدول الــسابق وجــود فرق ذو دلالة إحــصائية بـين منوســطى هـي درجات التطبيقين (القبلــى و البعــدى) فـى لـى المجموعة التجريبية فيى مهـــارة التمثيــل؛

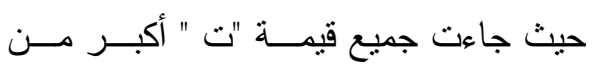

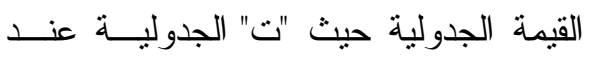
مستوى(0 . , •) ودرجــات حريـــة (ع (ب)

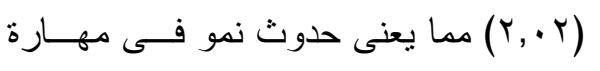
التمثيل لدى المجمو عة التجريبية .

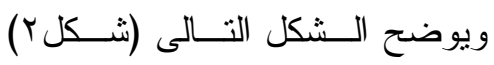
التمثيل البيانى للفرق بين متوسطات درجات 
يوجد فرق ذو دلالة إحـصائية عنــد

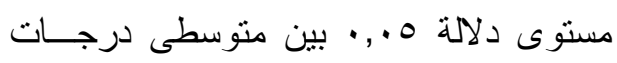

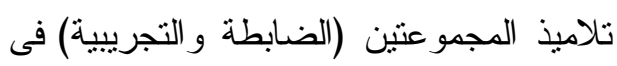

النطبيق البعـدى لمهــارة الكتابــة لــــالح

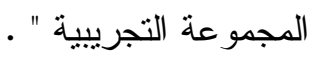

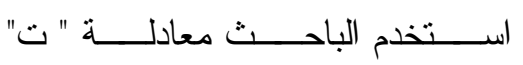

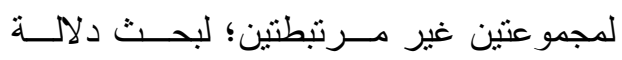

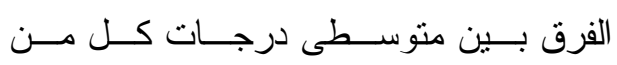

المجموعة التجريبية و المجموعة الضابطة فى دي

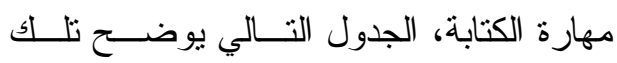

$$
\text { النتائج : مهارة }
$$

وفى ضوء تلاك النتائج، يمكن قبول الفرض : الثانى من فروض البحث وهو :

يوجد فرق ذو دلالة إحصائية عنـــ

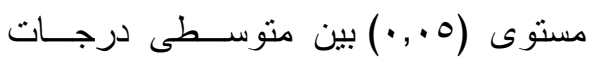

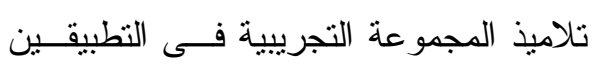

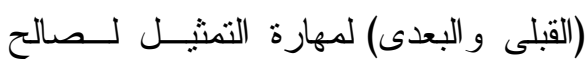

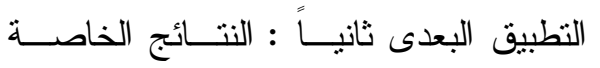
بمهارة الكتابة

للتحقق من صحة الفرض الثالث الذى

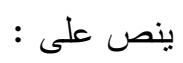
قيمة "ت" ودلالتها الإحصائية للفروق بين متوسطى درجات كل من المجموعتين (التجريبية و الضابطة) فى مهارة الكتابة بعدياً

\begin{tabular}{|c|c|c|c|c|c|c|c|}
\hline مستوى الدلالة & ت & ح.د & $\varepsilon$ & c & ن & مجمو عتا البحث & مهار ات اختبار التواصل الرياضى \\
\hline دالة & $1 ., 17$ & $V r$ & r, & $Q, \Gamma \mu$ & ro & ت & الكتابة \\
\hline & & & r, ro & $r, v r$ & $\varepsilon$. & ض & \\
\hline
\end{tabular}

تلاميذ المجموعتين التجريبية و الضابطة فـى التطبيق البعدى لمهارة الكتابة :

يتضح من الجدول الــسابق وجـود

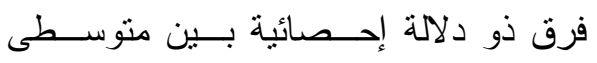

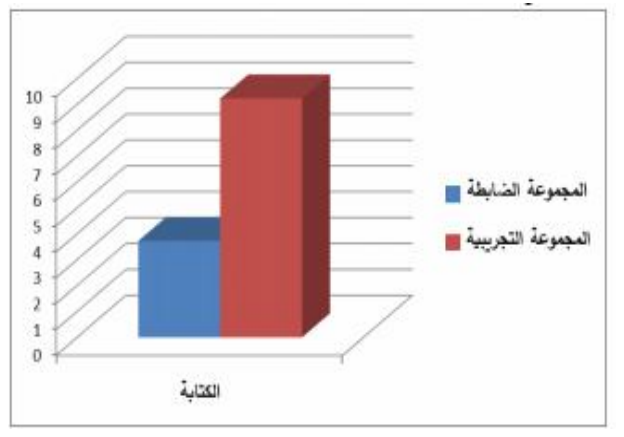

شكل (ץ): التمثيل البياني للفرق بين متوسطات

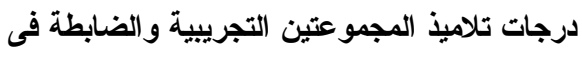
التطبيق البعدى لمهارة الكتابة

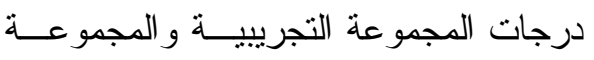

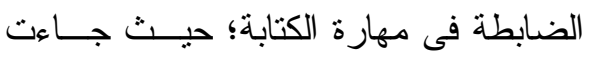

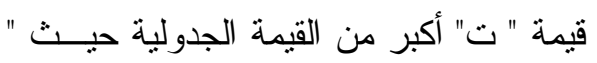

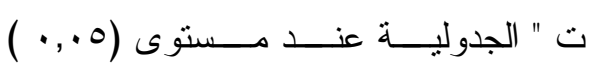
ودرجات حرية (Vr) = (1,99)؛ مما يدل

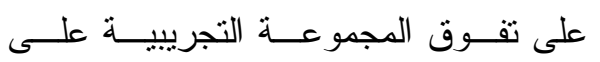
المجموعة الضابطة فى مهارة الكتابة.

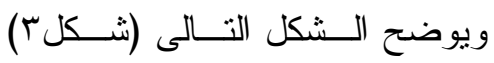
التمثيل البيانى للفرق بين منوسطات درجات 
يوجد فرق ذو دلالة إحسصائية بـين

متوسطى درجات تلاميذ المجموعة التجريبية

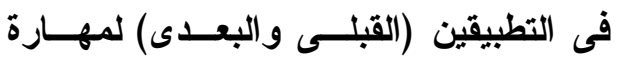
الكتابة لصالح التطبيق البعدى.

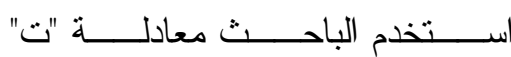

للمجموعات المرتبطة لبحث دلالة الفرق بـين

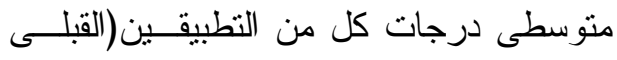

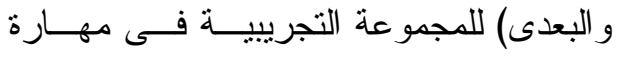

الكتابة، و الجدول التالي يوضح علده تلك النتائج :

وفى ضوء تلك النتيجة، يمكن قبول الفرض الثالث من فروض البحث وهو :

يوجد فرق ذو دلالة إحصائية عنـــ

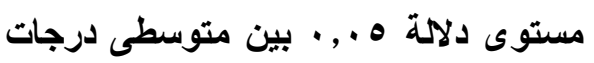
تلاميذ المجموعتين (الضابطة والتجريبية) فى التطبيق البعدى لمهارة الكتابة لــصالح المجموعة التجريبية

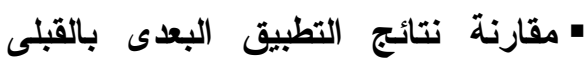

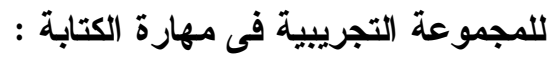

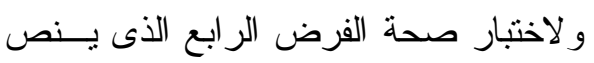
على :

قيمة "ت" ودلالتها الإحصائية للفرق بين متوسطى درجات كل من التطبيقين (القبلى و البعدى) للمجموعة التجريبية فى مهارة الكتابة

\begin{tabular}{|c|c|c|c|c|c|c|c|}
\hline مستوى الدلالة & $ت$ & د.ح & $\varepsilon$ & p & ن ن & القياس & مهار ات اختبار التواصل الرياضى \\
\hline 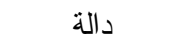 & $1,1,07$ & $r \varepsilon$ & 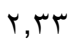 & $9, Y r$ & ro & بعدى & 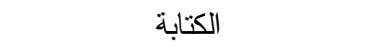 \\
\hline & & & $r, q r$ & $r, V \vee$ & ro & 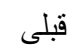 & \\
\hline
\end{tabular}

درجات تلاميذ المجموعــة التجريبيـة فـى يتضح من الجدول الـسابق وجــود

التطبيقين (القبلى و البعدى) مهارة الكتابة : لرعبد

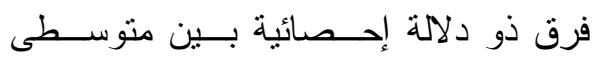

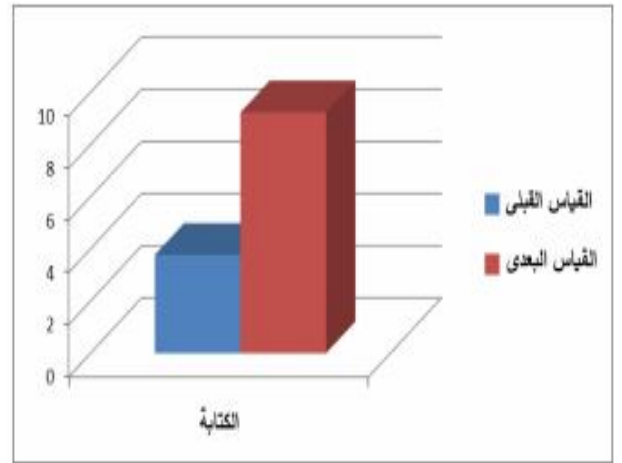

شكل (؛): التمثيل البياتي للفرق بين متوسطات درجات تلاميذ المجموعة التجريبية فى التطبيقين (القبلى و البعدى) لمهارة الكتابة

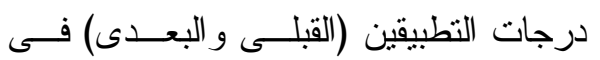

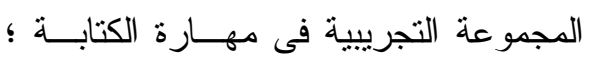
حيث جاءت قيمة "ت " أكبر مــن القيمــة فئة

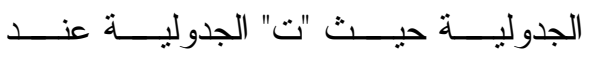

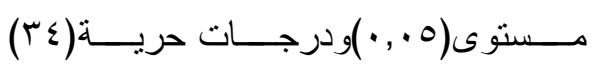
(Y, r r r)=

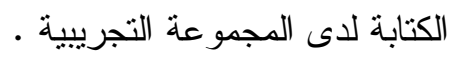
ويوضـــح الــشكل التــالى شـــــل (ع)التمثيل البيانى للفرق بــين منوســـات 
مستوى دلالة ه ., . بين متوســى

درجــات تلاميـــذ المجمــوعتين (الــضـابطة

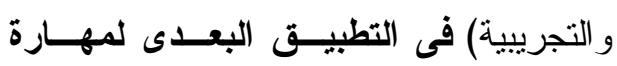

القز اعة لصالح المجموعة التجريبية

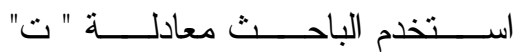

لمجمو عتين غير مــرتبطتين؛ لبحـــث دلالـــة الفرق بــين متوســطى درجــات كــل مــن المجموعة التجريبية و المجمو عة الضابطة فى مهارة القر اءة بعدياً، و الجدول التالي يوضـــح : نلك النتائج

وفى ضوء تللك النتائج، يمكن قبول الفرض الرابع من فروض البحث وهو :

يوجد فرق ذو دلالة إحصائية عنــــ

مستوى (0., •) بين منوســطى درجــات

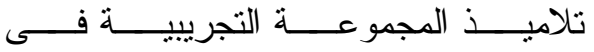

التطبيقين (القبلى و البعدى) لمهـــارة الكتابـــة لصالح التطبيق البعدى •

ثالثاً : النتائج الخاصة بمهارة القراعة للتحقق من صحة الفرض الخــامس الذى ينص على : - ال

"يوجد فرق ذو دلالة إحصائية عند

قيمة "ت" ودلالتها الإحصائية للفروق بين متوسطى درجات كل من المجموعتين

(التجريبية والضابطة) فى مهارة القز اعة بعدياً

\begin{tabular}{|c|c|c|c|c|c|c|c|}
\hline مستوى الدلالة & $ت$ & د. & $\varepsilon$ & b & ن & مجموعتا البحث & مهارات اختبار \\
\hline د د الة & $\Lambda, r$. & Vr & $r, 70$ & 1,01 & o & ت & القر اءة \\
\hline & & & $r, \wedge \vee$ & $r, r$. & $\varepsilon$. & ض & \\
\hline
\end{tabular}

تلاميذ المجمو عتين التجريبية و الضـابطة فـى التطبيق البعدى لمهارة القراعة :

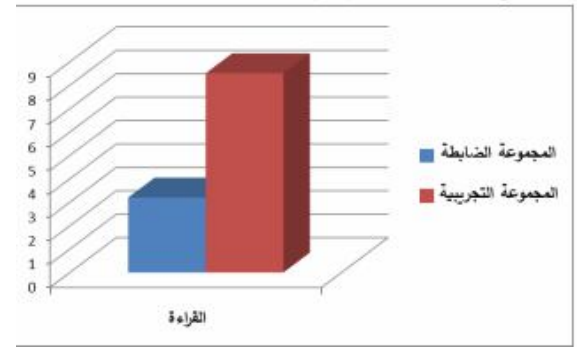

شكل (•): التمثيل البياني للفرق بين متوسطات درجات تلاميذ المجموعتين التجريبية والضابطة في (هن التئين التطبيق البعدى لمهارة القراءة
يتضح من الجدول الــسابق وجــود

فرق ذو دلالة إحــصائية بــين منتوســـى لمـ درجات المجمو عة التجريبيـــة و المجموعـــة الضـابطة فى مهارة القر اعة؛ حيث جـــاءت قيمة " ت" أكبر من القيمة الجدولية حيـــث "

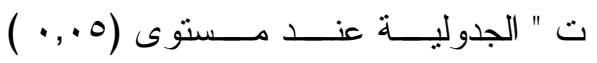
ودرجات حرية (سT)= (1,99)؛ مما بــدل على تفــوق المجموعــة التجريبيــة علــى المجمو عة الضابطة فى مهارة القر اءة.

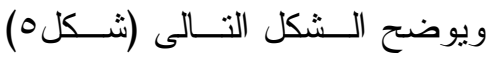

التمثيل البيانى للفرق بين منوسطات درجات 
يوجد فرق ذو دلالة إحـصائية بـين

متوسطى درجات تلاميذ المجموعة التجريبية

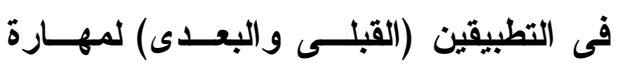
القز اعة لصالح التطبيق البعدى.

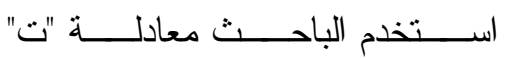

للمجمو عات المرتبطة لبحث دلالة الفرق بـين لئن

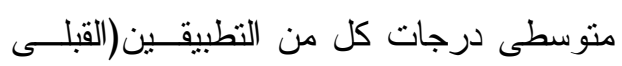

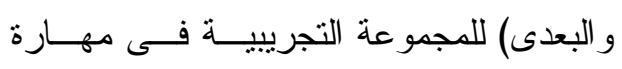
القر اءة، و الجدول التالي يوضح تللك النتائج :
وفى ضوء تللك النتيجة، يمكن قبــول

الفرض الخامس من فروض البحث و هو : يوجد فرق ذو دلالة إحصائية عند مستوى دلامة ه. , · بين متوسطى درجات تلاميذ المجموعتين (الضابطة و التجريبية) فى التطبيق البعدى لمهارة القراعة لصالح المجموعة التجريبية مقارنة نتائج التطبيق لمعاعيق البعدى بالقبلى للمجموعة التجريبية فى فئه مهارة القراعة : باعكائ و لاختبار صحة الفرض السادس الذى ينص على :

قيمة "ت" ودلالتها الإحصائية للفروق بين متوسطى درجات كل من التطبيقين

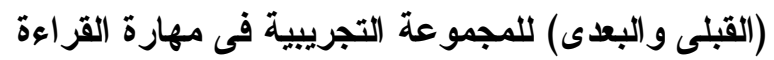

\begin{tabular}{|c|c|c|c|c|c|c|c|}
\hline مستوى الدلالة & $ت$ & ح.د & $\varepsilon$ & 5 & ن & القياس & مهارات اختبار التواصل الرياضي \\
\hline 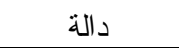 & $I T, \cdot V$ & $r \leq$ & $r, 70$ & $\Lambda, 01$ & ro & 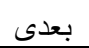 & القر اءة \\
\hline & & & $r, r_{T}$ & $r, \varepsilon$. & ro & 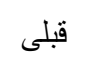 & \\
\hline
\end{tabular}

تلاميذ المجمو عة التجريبيــة فــى التطبية لين (القبلى و البعدى) لمهارة القر اءة :

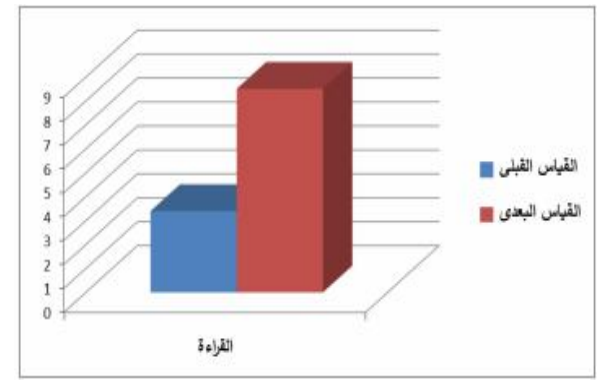

شكل (†): التمثيل البياتي للفرق بين متوسطات درجات تلاميذ المجموعة التجريبية فى التطبيقين يتضح من الجدول الــسابق وجــود فروق ذو دلالة إحصائية بــين منوســطى ملى درجات التطبيقين (القبلــى و البعــدى) فـى لـى المجمو عة التجريبية فى مهـــارة القـــر اءة ؛ حيث جاءت جميع قيم "ت " أكبر من القيمة

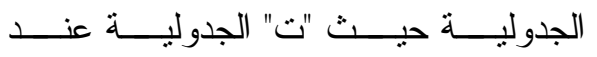
مستوي(0 . , •) ودرجــات حريـــة (ع ب)

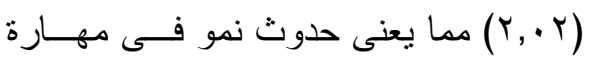
القر اعة لدى المجموعة التجريبية . (القبلى والبعدى) لمهارة القراعة

ويوضح الــشكل التــالى (شــكل 1)

التمثيل البيانى للفرق بين متوسطات درجات 


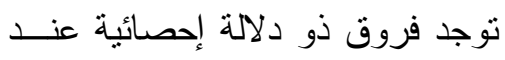

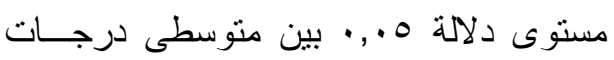

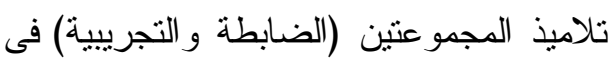

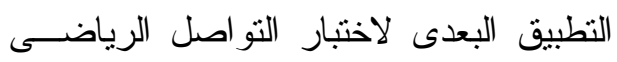

ككل لصالح المجموعة التجريبية".

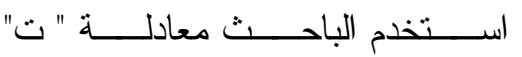

لمجموعتين غير مـــرتبطتين؛ لبحــث دلالــــة

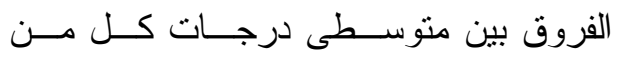
المجموعة التجريبية و المجموعة الضابطة فى ملى لـئ

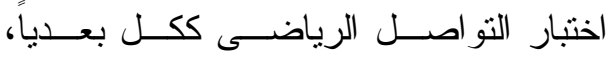
و الجدول التالي يوضح تلك النتائج :

وفى ضو ء تللك النتائج، يمكن قبــول

الفرض السادس من فروض البحث وهو :

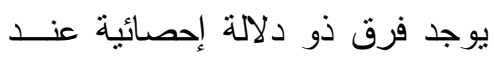

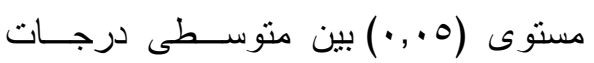

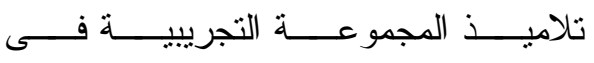

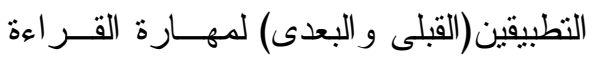

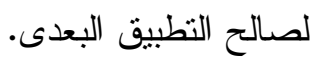
• ر رابعاً: النتائج الخاصة باختبار التواصل الرياضى ككل :

للتحقق من صحة الفرض الـسابع الـــى : لــ ينص على : قيمة "ت" ودلالتها الإحصائية للفروق بين متوسطى درجات كل من المجموعتين

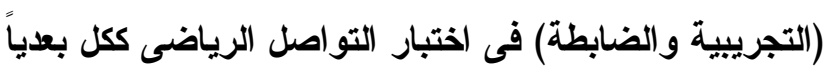

\begin{tabular}{|c|c|c|c|c|c|c|c|}
\hline مستوى الدلالة & 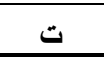 & ح.د & $\varepsilon$ & م & ن & مجموعتا البحث & اختبار التواصل الرياضي \\
\hline ل & $1 \cdot, \lambda r$ & vr & $0, \wedge \varepsilon$ & $Y \uparrow, I V$ & ro & $ت$ & الاختبار ككل \\
\hline & & & 7,11 & $11, \cdot 1$ & $\varepsilon$. & 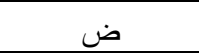 & \\
\hline
\end{tabular}

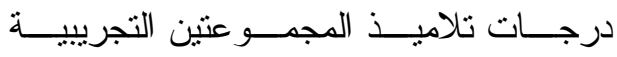
و الضابطة فـى التطبيــق البعـدى لاختبــار يتضح من الجدول الــسابق وجــود التو اصل الرياضى ككل :

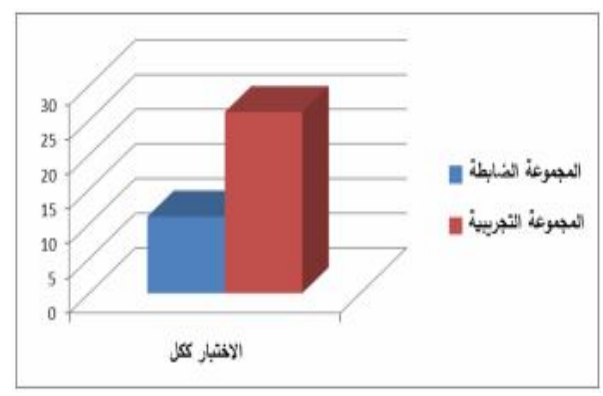

شكل (V): التمثيل البياني للفروق بين متوسطات

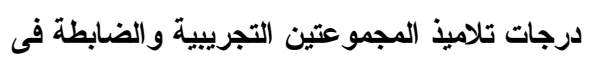

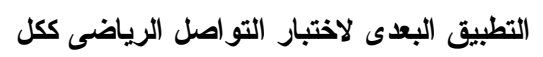

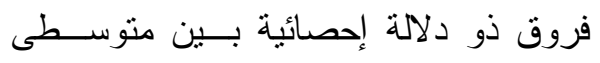

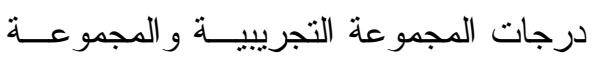

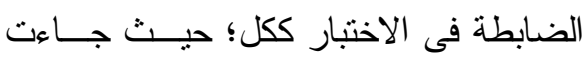

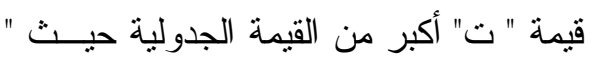

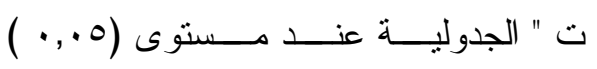
ودرجات حرية (Vr) = (1,99)؛ مما يدل

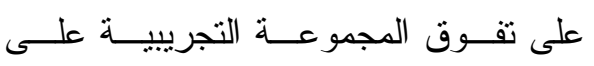

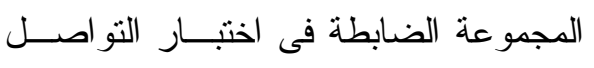

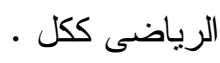
ويوضح الـشكل التــالى (ثـــل V) التمثيل البيانى للفــروق بــين منوســــات 
توجد فروق ذو دلالة إحـصائية بـين

متوسطى درجات تلاميذ المجموعة التجريبية

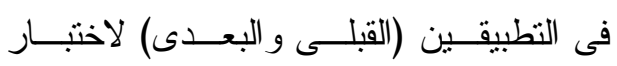

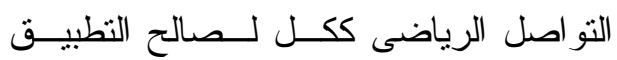

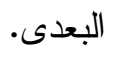

اســـــتخدم الباحســــث معادلــــــة "ت

للمجموعات المرتبطة لبحث دلالة الفروق بين منوسطى درجات كل من النطبيقين (القبلــى

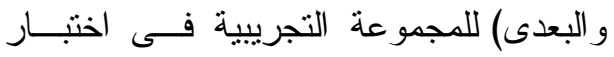
التو اصل الرياضى ككل، و الجــدول التــالي يوضح تلك النتائج :
وفى ضوء تللك النتيجة، يمكن قبول الفرض السابع من فروض البحث وهو : توجد فروق ذو دلالة إحصائية عند مستوى دلالة 0 ., • بين منوسطى درجـات تلاميذ المجمو عتين (الضابطة و التجريبيــة) فى التطبيــق البعـــى لاختبـــار التواصــل الرياضى ككل لصالح المجموعة التجريبية . • مقارنة نتائج التطبيق البعدى بالقبلى للمجموعة التجريبية فى اختبار التواصل

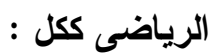
و لاختبار صحة الفرض الثامن الذى يـــص على :

قيمة "ت" ودلالتها الإحصائية للفروق بين متوسطى درجات كل من التطبيقين (القبلى و البعدى) للمجموعة التجريبية فى مهارات اختبار التواصل الرياضى ككل

\begin{tabular}{|c|c|c|c|c|c|c|c|}
\hline مستوى الدلالة & $ت$ & ح. د & $\varepsilon$ & م & ن & القياس & مهارات اختبار التو اصل الرياضى \\
\hline 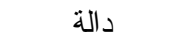 & $19, \pi r$ & $r \varepsilon$ & $0, \wedge \varepsilon$ & $r 7 ., 1 V$ & ro & بعدى بع & الاختبار ككل \\
\hline & & & $\varepsilon, 9 v$ & $11, \varepsilon r$ & ro & 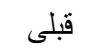 & \\
\hline
\end{tabular}

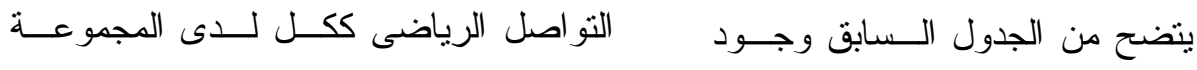

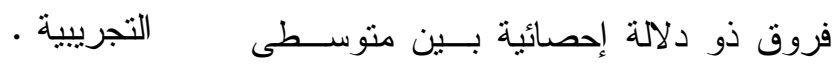

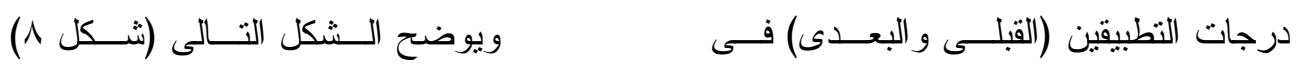

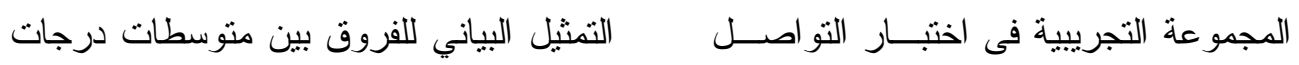

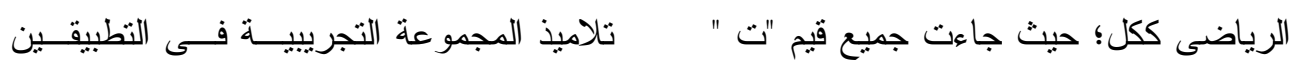

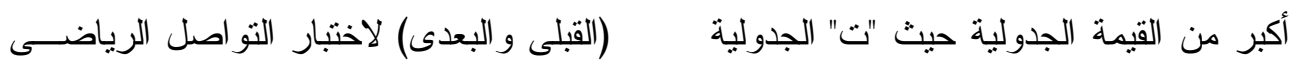

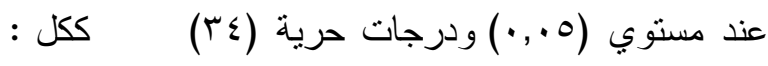

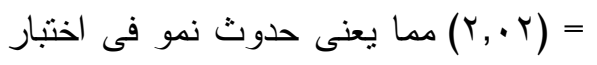


(القبلى و البعدى) لاختبار مهار ات التو اصــل الرياضى ككل لصالح التطبيق البعدى .

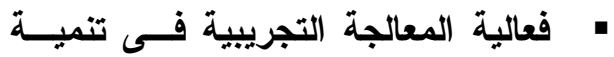
مهارات التواصـل الرياضــى (حجــ

$$
\text { (التأثير) : }
$$

لتحديد فعالية المعالجة التجريبية فـى

تتمية التواصـلـ الرياضــى؛ قـــام الباحــث

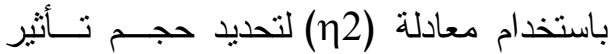

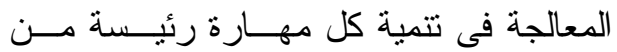

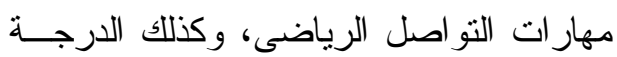

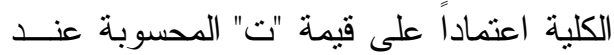

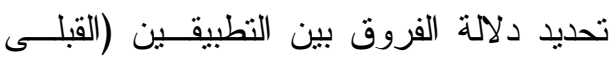

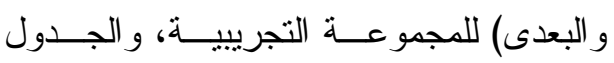

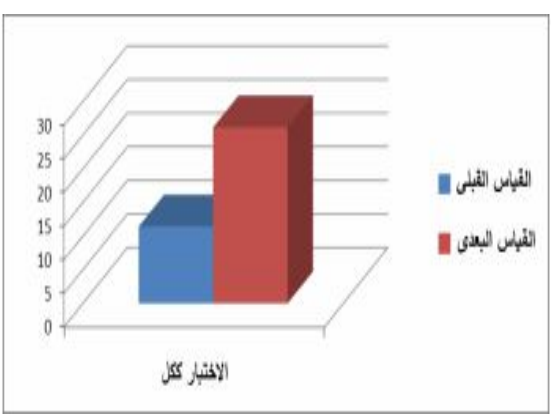

شكل (^): التمثيل البياني للفروق بين متوسطات درجات تلاميذ المجموعة التجريبية فى التطبيقين (القبلى و البعدى) لاختبار التو اصل الرياضى ككل فئل

وفى ضوء تللك النتائج، يمكن قبــول

الفرض الثامن من فروض البحث و هو : توجد فروق ذو دلالة إحصائية عند مستوى (0., •) بين منوسـطى درجـات تلاميذ المجموعة التجريبية فــى النطبية لـين

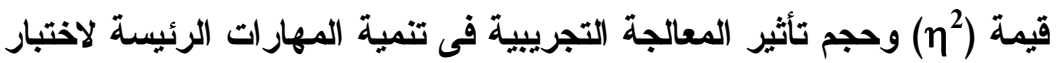

التواصل الرياضى و الدرجة الكلية

\begin{tabular}{|c|c|c|c|}
\hline حجم التأثير & $\eta^{2}$ & $ت$ & مهار ات اختبار التو اصل الرياضي \\
\hline كبير & • & $1, r, r q$ & التمثيل \\
\hline كبير & $\cdot, \Delta r$ & $1 Y, 07$ & 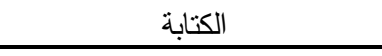 \\
\hline كبير & $\cdot$, , I & $I, \cdot \mathrm{V}$ & 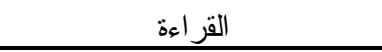 \\
\hline كبير & $\cdot, 91$ & $19, r r$ & الاختبار ككل \\
\hline
\end{tabular}

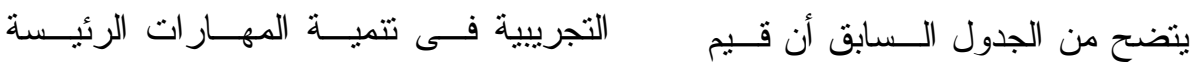

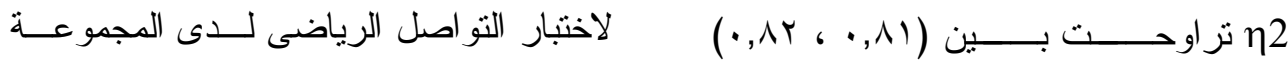

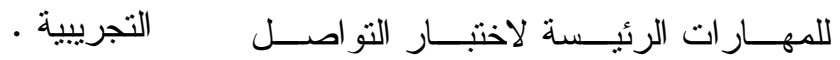

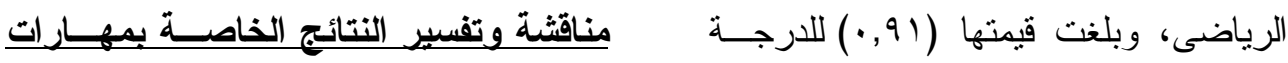

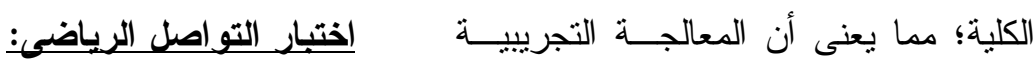

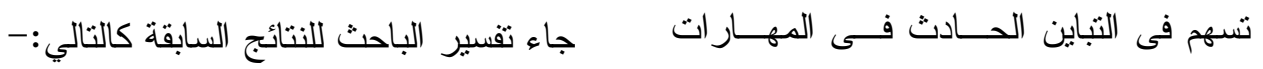
الرئيسة لاختبار التواصل الرياضى بنـسبة

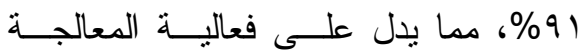


- ساعدت اســتز انيجية الخـــر ائط الذهنيــة التلاميذ على وصف العلاقات الرياضــية المتضمنة فى شكل هندسى أو مـشكلات لفظية لآخرين وظهر هذا من خلال نتائج تلاميذ المجموعة التجريبية و الضابطة فى لهي التطبيق البعدى لإختبار مهار ات التواصل

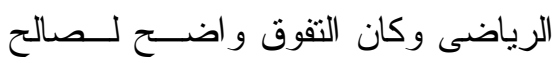
المجمو عة التجريبية. - أسهمت إستر اتيجية الخر ائط الذهنية فـى فئل تقدم ملحوظ على أداء تلاميذ المجموعــة التجريبية من خلال جمع أكبر قدر مــن مئن

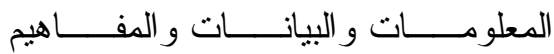
و المصطلحات و الرموز الرياضــية فــى لـي

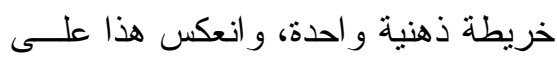

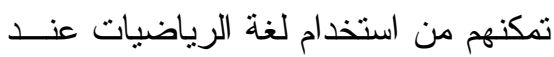

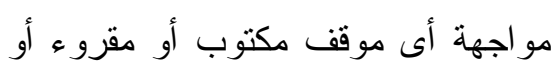
مرسوم و إدر اكه وتفــسيره وتوضـــيحه

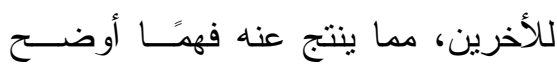
و أعمق للأفكار الرياضية.

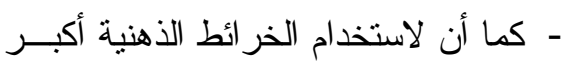

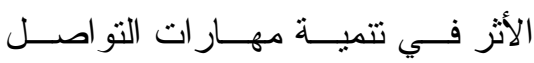
الرياضى لاى تلاميذ المرحلة الإعدادية؛

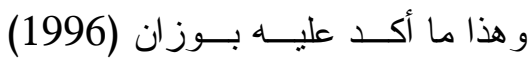
فى نظريته بأن الخر ائط الذهنية نسهم فى لـ التعلم بـشكل أفــل مــن الأســاليب التقليدية .
لقد جاءت نتــائج البحـــ لــصالح التلاميذ اللذين درسوا باستخدام اســتر اتيجية

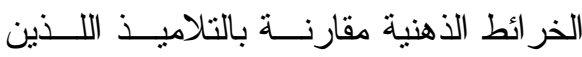

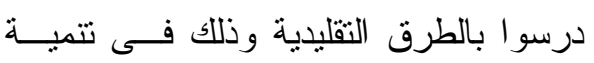

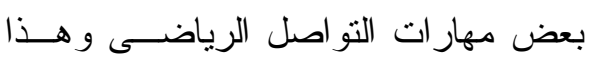
يشير إلــى فعاليــة اســتخدام إســتز اتيجية

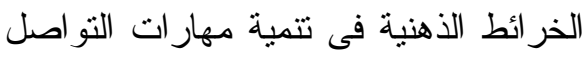

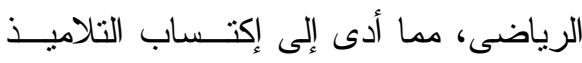
اللذين استخدمو ا إستر اتيجية الخر ائط الذهنية إلهابية بعض مهار ات التو اصل الرياضى و استخدام

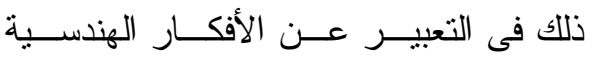

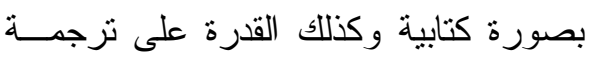

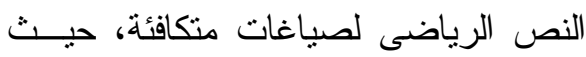

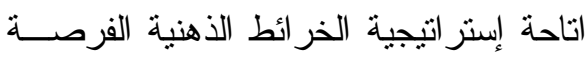

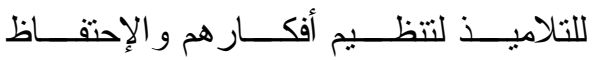
بالمعلومات لفترات طويلة مما عمل علــى لفي بقاء أثز التعلم. بعلم - من اهم مميز ات إستر اتيجية الخــــر ائط الذهنية العمل علـى تلخــيص المــادة العلمية وعرض أفكار ها بشكل مــنظم ومسلسل وقد بينت النتائج تمكن التلاميذ اللذين استخدمو إستنر اتيجية الخــر ائط الذهنية من تلخيص ما فهموه من أفكار

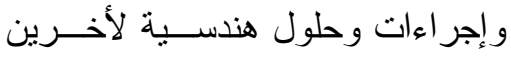

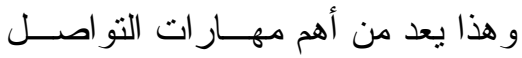

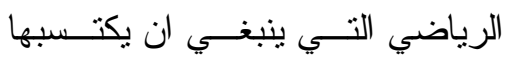

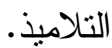




$$
\begin{aligned}
& \text { الاستر اتيجية فى التدريس ومن ثم فعاليتها فى } \\
& \text { - أدى استخدام الخر ائط الذهنية إلى فهـم } \\
& \text { تتمية مهار ات التو اصل الرياضى. }
\end{aligned}
$$

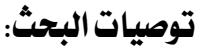

$$
\begin{aligned}
& \text { فى ضو ء ما أسفرت عنه نتائج هذا البحـــث، } \\
& \text { فإن الباحث يقدم التوصيات التالية: }
\end{aligned}
$$

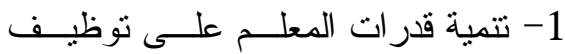

$$
\begin{aligned}
& \text { استر اتيجية الخر ائط الذهنية وتــدريب }
\end{aligned}
$$

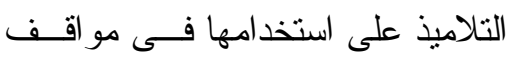

$$
\begin{aligned}
& \text { تعليم وتعلم الرياضيات. } \\
& \text { 2- يجب دمج استراتيجية الخر ائط الذهنية } \\
& \text { داخل مقرر ات الرياضيات لما لها مـنـ } \\
& \text { دور إيجابى فى جعـلـ التلميــذ أكتثر } \\
& \text { فاعلية و انتباه أثناء الموقف التعليمى. }
\end{aligned}
$$

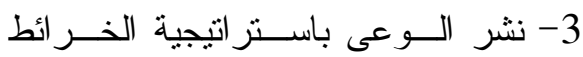

$$
\begin{aligned}
& \text { الذهنية و أهميتها ودور ها فـى نتى تتميــة }
\end{aligned}
$$

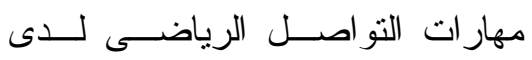

$$
\begin{aligned}
& \text { التلاميذ. } \\
& \text { 4- تــدريب المــوجهين علــى اســتخدام } \\
& \text { استر اتيجية الخرائط الذهنية فى تدريس } \\
& \text { الرياضيات. } \\
& \text { 5- يجب أن تضمن بر امج إعداد معلمسى لرئي }
\end{aligned}
$$

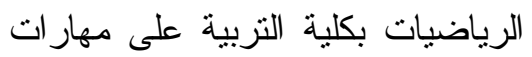

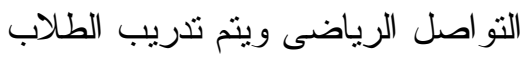

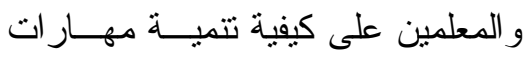

$$
\begin{aligned}
& \text { التو اصل الرياضى لدى التلاميذ. } \\
& \text { 6- تطوير المناهج الدر اسية بحيث تعدـل لــل }
\end{aligned}
$$

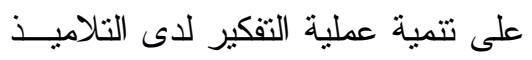

$$
\begin{aligned}
& \text { دلالة الرموز و المصطلحات و الأثــكال }
\end{aligned}
$$

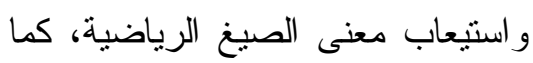

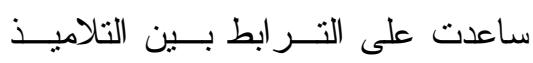

$$
\begin{aligned}
& \text { و المعلمين - ماعل } \\
& \text { - ساعدت الخرائط الذهنية على المزيــد } \\
& \text { من الكتابة الرياضــية بـشكل مــنظم }
\end{aligned}
$$

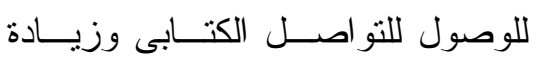

$$
\begin{aligned}
& \text { القدرة على استخدام لغـــة الرياضـــات }
\end{aligned}
$$

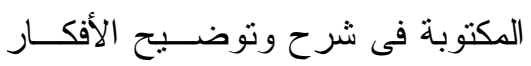

$$
\begin{aligned}
& \text { و العلاقات الرياضية و التبرير و البر هان }
\end{aligned}
$$

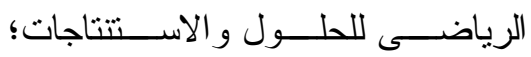

$$
\begin{aligned}
& \text { وبالتالى فتح قنــــات للتو اصــل بــين } \\
& \text { التناميذ و الآخرين تساعدهم فى التعبير } \\
& \text { عن أفكار هم بطريقة مكتوبة . }
\end{aligned}
$$

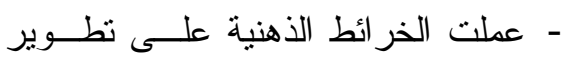

$$
\begin{aligned}
& \text { وتعميق للمفاهيم الرياضية؛ فهم يقومون } \\
& \text { بابتكار ومقارنة و استخدام أشكالاً كثيرة } \\
& \text { متتوعة من التمثيلات الرياضية مثــل }
\end{aligned}
$$

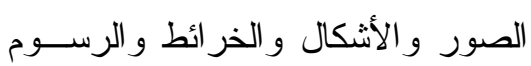

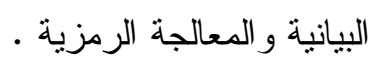

$$
\begin{aligned}
& \text { و اتفق البحث الحالى مع در اسة كـلـل } \\
& \text { من در اسة أمينة راغب (11 (1))، ودراسة }
\end{aligned}
$$

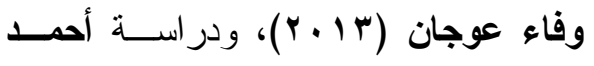

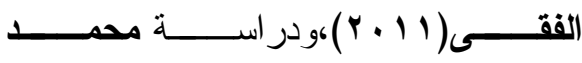

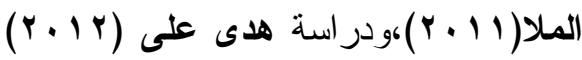

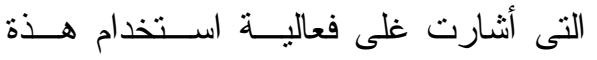


4- در اسة أثر استخدام إستر اتيجية الخرائط

الذهنية فى تدريس الرياضيات لتتميــة

القدرة على حل المشكلات الرياضــية لـاضية لدى تلاميذ المرحلة الإعدادية.

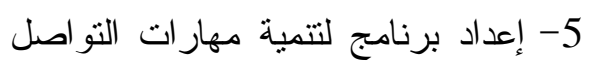

الرياضى لدى معلمى الرياضيات قبـــل

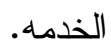

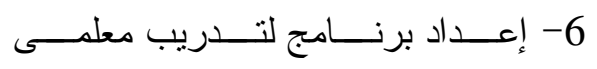

الرياضيات على كيفية عمل واستخدام

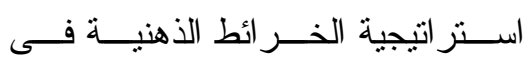

المر احل التعلمية المختلفة.

المراجع :
وتتمى لــديهم مهــار ات التواصــل الرياضى.

7- يجب على المعلم أن يُفعل دور التلميذ

أثناء عملية التدريس وجعلــهـ أكتهـر

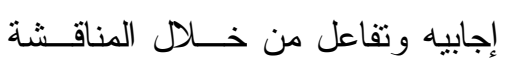

و الحوار ومحاولة إثارة تقكيرة مـــع تقديم التعزيزات المناسبة.

8- الإستقادة من دليل المعلم القائم علــى لفئل

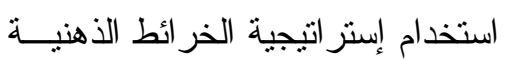

فى تدريس الرياضيات فــى تتميــة مهار ات التو اصل الرياضى.

\section{البحوث والدراسات المقترحة:}

1- أحمد أنور حسـن الفقـى (2011م):

فى ضو ء ما أسفرت عنه نتائج البحث، يقوم

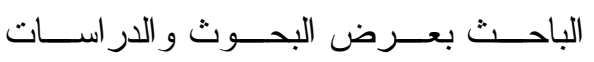
المستقبلية التاليه:

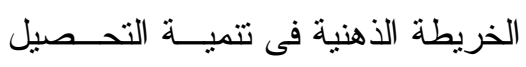
وبعض المهار ات التاريخية لدى تلاميذ

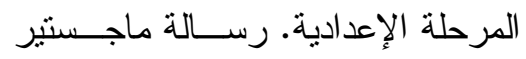
غير منشورة. كلية التزبية. جامعة عين شمس.

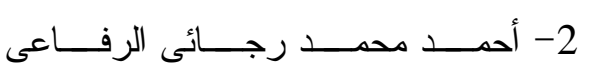

(2008م): استر اتيجية مقترحة لتتميــة التو اصل الرياضى و التحصيل و الإتجاة نحو الرياضيات لدى تلاميذ المرحلـــة

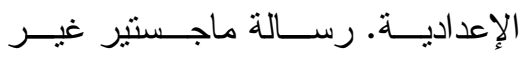

منشورة، كلية التزبية، جامعة طنطا. 3- أحمد محمود عفيفــى(2008م): أنــر

استخدام استر اتيجية ما ور اء المعرفـــة
1- در اسة استخدام استر اتيجية الخـــر ائط

الذهنية فى تدريس الرياضيات لتتمية

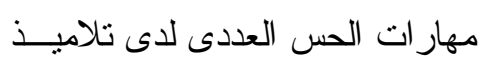
المرحلة الإعدادية.

2- در اسة أسباب تدنى مهار ات التواعله اصل

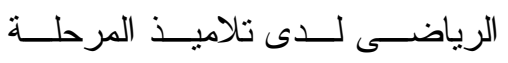

$$
\text { الإعدادية. }
$$

3- در اسة استخدام استر اتيجية الخـــر ائط

الذهنية فى تدريس الرياضيات لتتمبة

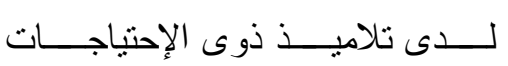

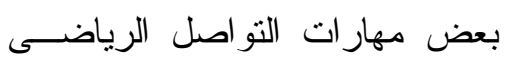


رسالة ماجستير ـ كلية التربية جامعــة

المنصورة.

9- رمــضان مــسعد بــدوى(2003م):

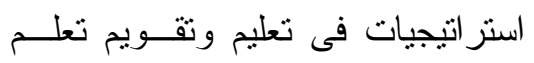

الرياضيات، عمّان، دار الفكر .

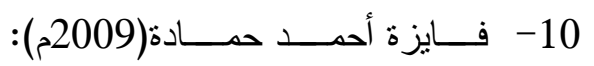

استخدام التدريس التبادلى لنتمية التفكير

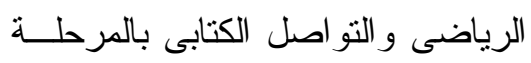

الإعدادية فى ضـــوء بعــ ولـ معـايير

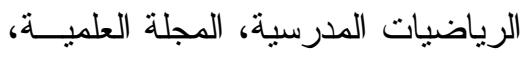

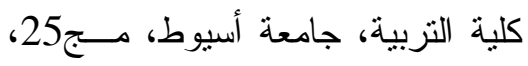

14، ص ص 299-332.

11- مها محمد الشقرة(2006م): تقــــيم

منهاج الرياضيات الحالى لتعليم الــصم

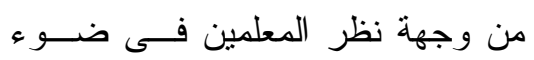

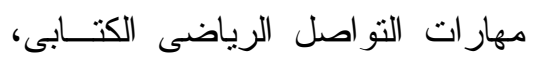

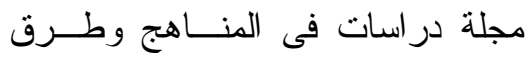

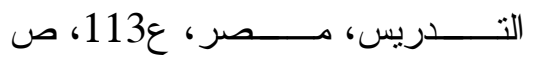

$$
\text { ص:122-151. }
$$

12- نانسى مارجيو از (2004م): تخطيط

الــذهن. ترجمــة الـشركة العربيـــة.

الرياض: دار الميمان للنشر و التوزيع.

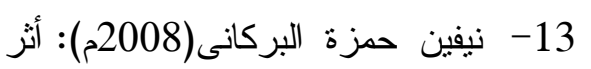

التــدريس باســـتخدام اســـتر اتيجيات

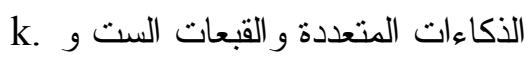

فى التحصيل و التو اصل و الترابط

الرياضى لدى طالبات الصف الثالـــث
على التحـــيل وتتميـــة مهــار ات

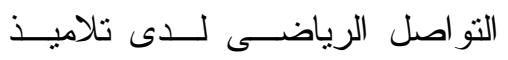
الـــصف الأول الإعــــدادى، مجلــــة

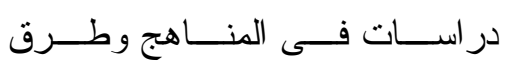

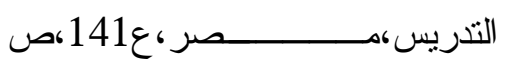

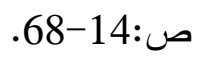

4- أمينة راغب حسن حريرة(2011م):

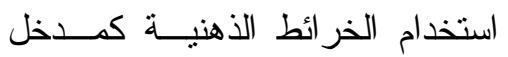

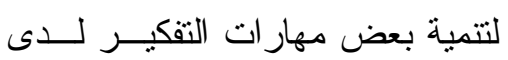

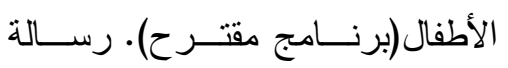

ماجستير • كلية البنات. جامعة عـين شمس.

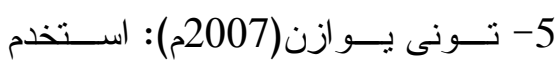

عقلك. ترجمة مكتبة جرير • الرياض:

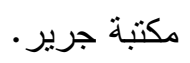
6- نونى يوزان وبارى يوزان(2006م).

خريطة العقل. ترجمة مكتبة جريــر . الرياض: مكتبة جرير •

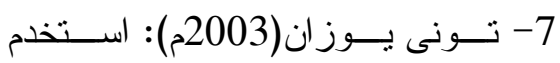

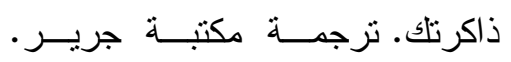
الرياض: مكتبة جرير • 8- حنان حسن خليل(2008م): تـصميم ونشر مقرر الكترونى فى تكنولوجيا التعلم فى ضوء معايير جودة الــتعلم الإككترونى لتتمية الجو انب المعرفيــة فئة

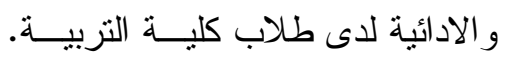


17-Buzan ,T. (2004). Mind Maps for Kids Max your Memory and concentration. Hammersmith: Thomson's.

18-Buzan,T.(2005). The Ultimate Book of Mind maps. Hammersmith: Thomson's.

19-Buzan,T. \& Buzan ,B. (2006). The Mind Maps Book. BBC. Books London.

20-Greenes, c \&othors (1992). Stimulating Communication in Mathematics. Journal of ArithmeticTeacher. October.

21-HuginsBand Maiste. T (1999). Communication in mathematics ERIC.ED. 439016.

22-Riedesel. C (1995). An Analysis of An Authentic Assessment Technique: Comparing the spoken and the written Mathematical Communicative abilities of Grade 4 students. (D. A. I). v56, n10.

23-Schwarz,j(1999). Vocabulary and Its effects on Mathematics Instruction. ERIC. ED439017.

24-Wadington. E \&others (1992). Have A problem? Make the writing-Mathematics

Connection. Journal of Arithmetic Teacher,

$$
\begin{aligned}
& \text { المتوسط بمدينة مكة المكرمة، رسالة } \\
& \text { دكتور اة غير منشورة، مكة المكرمة. } \\
& \text { 14- هــــ علــى إبــر اهيم(2012م): }
\end{aligned}
$$

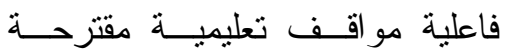

$$
\begin{aligned}
& \text { مصممة فى ضوء الخر ائط الذهنبــة } \\
& \text { لتتمية التفكيــر الإبــــاعى والـــكاء } \\
& \text { البصرى المكانى لأطفال الروضـــة. } \\
& \text { رسالة ماجستير . كلية التربية. جامعة لاطعل الروضه } \\
& \text { حلوان. } \\
& \text { 15- هديل أحمد وقاد(2009م): فعالية }
\end{aligned}
$$

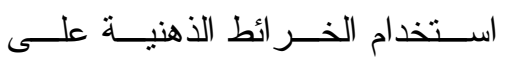

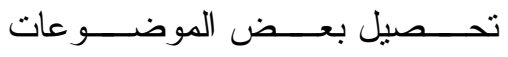

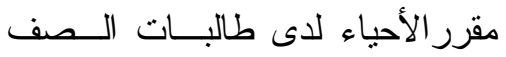

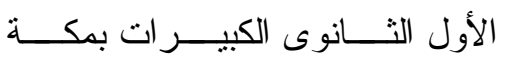

$$
\begin{aligned}
& \text { المكرمة، رســالة ماجسـتير غيـر } \\
& \text { منشورة، كلية التربيــة، جامعــة أم }
\end{aligned}
$$

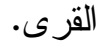

$$
\begin{aligned}
& \text { 16- وفاء سليمان عوجــان(2013م): } \\
& \text { تصميم ودر اســة فاعليــة برنــامج } \\
& \text { تعليمى باستخدام الخرائط الذهنية فى }
\end{aligned}
$$

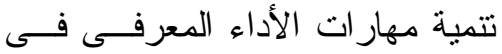

$$
\begin{aligned}
& \text { مساق تربية الطفل فى الإسلام لــدى } \\
& \text { طالبات كلية الأميرة عالية الجامعية. } \\
& \text { كلية التربية. جامعة القصيم. المجلـــة } \\
& \text { التزبوية الدولية المتخصصة. المجلد } \\
& \text { الثانى. العدد السادس. يونيو. }
\end{aligned}
$$

